\title{
Austria: 2008 Article IV Consultation-Staff Report; Public Information Notice on the Executive Board Discussion; and Statement by the Executive Director for Austria
}

Under Article IV of the IMF's Articles of Agreement, the IMF holds bilateral discussions with members, usually every year. In the context of the 2008 Article IV consultation with Austria, the following documents have been released and are included in this package:

- $\quad$ the staff report for the 2008 Article IV consultation, prepared by a staff team of the IMF, following discussions that ended on March 17, 2008, with the officials of Austria on economic developments and policies. Based on information available at the time of these discussions, the staff report was completed on May 22, 2008. The views expressed in the staff report are those of the staff team and do not necessarily reflect the views of the Executive Board of the IMF;

- a Public Information Notice (PIN) summarizing the views of the Executive Board as expressed during its June 13, 2008 discussion of the staff report that concluded the Article IV consultation; and

- $\quad$ a statement by the Executive Director for Austria.

The document listed below has been or will be separately released.

Selected Issues Paper

Financial System Stability Assessment—Update

The policy of publication of staff reports and other documents allows for the deletion of market-sensitive information.

Copies of this report are available to the public from

International Monetary Fund $\bullet$ Publication Services

$70019^{\text {th }}$ Street, N.W. • Washington, D.C. 20431

Telephone: (202) 623-7430 • Telefax: (202) 623-7201

E-mail: publications@imf.org • Internet: http://www.imf.org

Price: $\$ 18.00$ a copy

\section{International Monetary Fund}

Washington, D.C. 



\title{
INTERNATIONAL MONETARY FUND
}

\author{
AUSTRIA \\ Staff Report for the 2008 Article IV Consultation \\ Prepared by the Staff Representatives for the 2008 Consultation with Austria \\ Approved by Poul M. Thomsen and Michael T. Hadjimichael
}

May 22, 2008

\section{Executive Summary}

Background. The Austrian economy has been doing well in recent years. This was the combined result of solid economic policies, structural reforms, wage moderation, and an early focus on Central, Eastern and Southeastern Europe (CESE). Economic growth exceeded 3 percent in both 2006 and 2007-significantly higher than the euro area average and than growth in major trading partners - with strong employment growth and unemployment coming down to about 4 percent. The external position remained strong, but inflation has been under upward pressure, as elsewhere in the euro area. The structural fiscal position has not improved significantly during the economic upturn.

\section{Key issues and recommendations}

- Short-term outlook. In response to global economic developments staff expects growth to come down to around 2 percent in 2008-09. Inflation is expected to reach close to 3 percent in 2008. To sustain growth and minimize the negative effects of a weaker external environment, keeping Austria competitive will be critical. This will require continued wage moderation.

- $\quad$ Fiscal policies. The government has recently confirmed its objective of a structurally balanced budget by 2010. However, reaching that target will be challenging. The structural deficit in 2007 was about 1 percent of GDP, and the authorities have announced tax cuts for 2010 to the tune of another 1 percent of GDP. To achieve the required lasting expenditure savings, a fundamental reform of fiscal federal relations is needed.

- $\quad$ Financial sector. The rapid expansion of Austrian financial institutions in CESE has been beneficial for both Austria and the host countries. However, it has also brought greater vulnerabilities and requires active credit risk management, in particular with regard to foreign currency lending. The authorities are aware of the need to continue strengthening financial sector policies and governance, and this prompted a reorganization of banking supervision, with a larger role for the Austrian National Bank (OeNB). The financial sector has so far not been affected significantly by the recent global financial turmoil, although funding costs have gone up.

- $\quad$ Structural policies. Structural reforms need to be implemented as planned, with a special focus on further deregulation, increasing competition in domestic markets, and labor market reforms. 


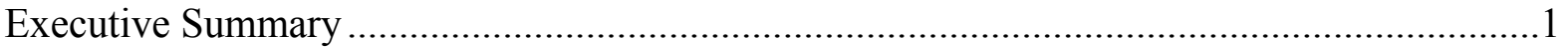

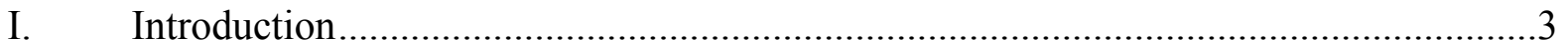

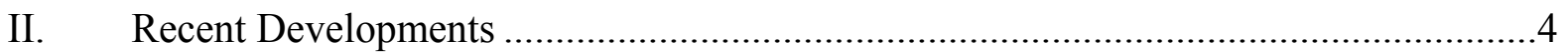

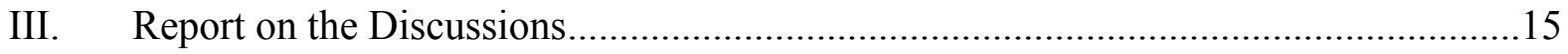

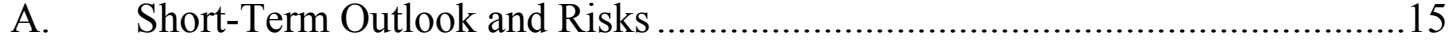

B. Competitiveness, Wages, and Inflation .................................................... 17

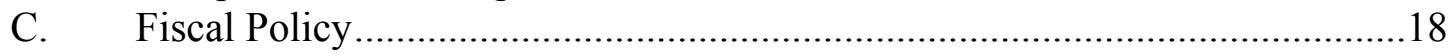

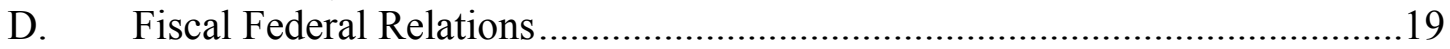

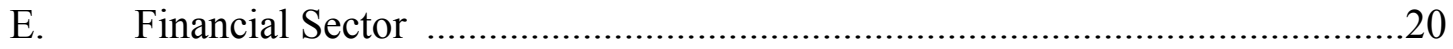

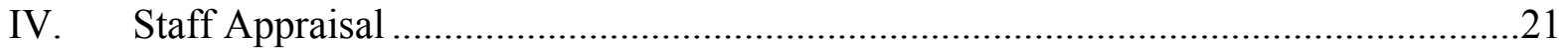

\section{Text Boxes}

1. Key Fund Policy Recommendations and Implementation..........................................

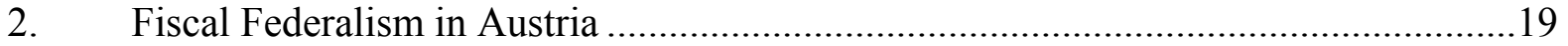

3. Main Recommendations of the FSAP Update ......................................................21

Tables

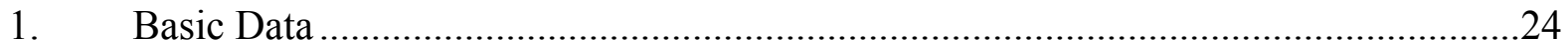

2. Medium-Term Macroeconomic Framework, 2003-12 ….........................................25

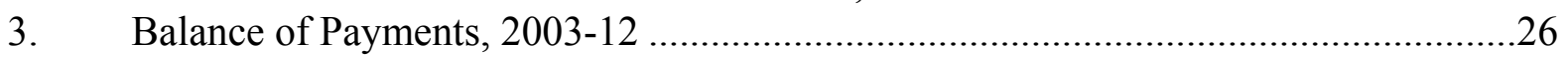

4. General Government Accounts, 2002-10 .......................................................27

5. Financial Soundness Indicators for the Banking Sector, 2004-07 ..........................28

Figures

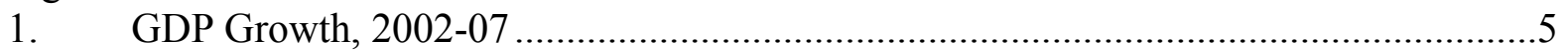

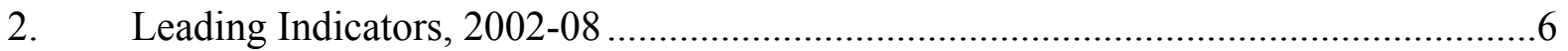

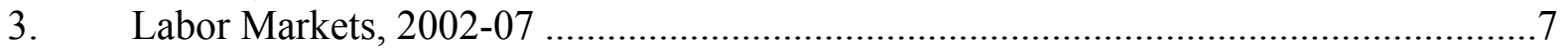

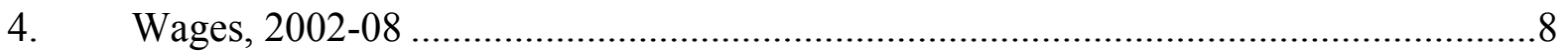

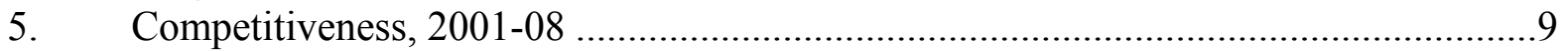

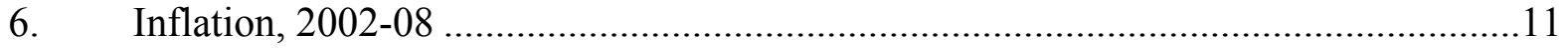

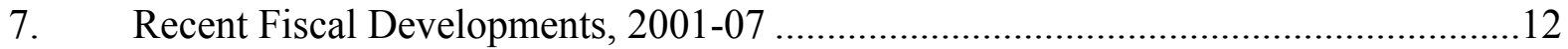

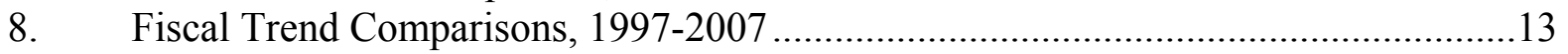

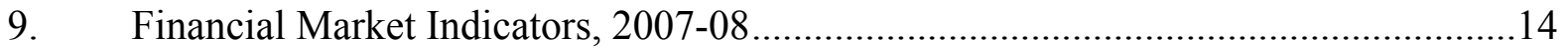

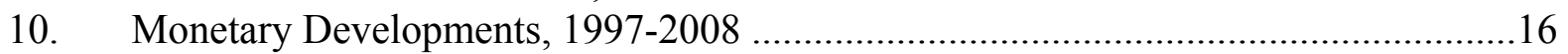




\section{INTRODUCTION ${ }^{1}$}

\section{A mix of solid economic policies, wage moderation, and an early orientation} towards Eastern Europe explain Austria's strong economic performance. Economic policies have contributed to this performance by a focus on macroeconomic stability and structural reforms. Wage moderation, resulting from a strong social partnership, has preserved competitiveness and supported export led growth, which has significantly exceeded the euro area average in recent years. The private sector has reaped the benefits from an early entry into fast growing CESE, including in the financial industry. The overall direction of Austria's economic policies has been supported by the Fund (Box 1).

\section{Box 1. Key Fund Policy Recommendations and Implementation}

During Article IV consultations in recent years, the Executive Board commended the authorities on their record of sound macroeconomic policies and structural reforms. ${ }^{1}$ Overall, policy implementation has been largely consistent with Fund policy advice.

Fiscal policy. Directors endorsed the authorities' medium-term macroeconomic policy objectives of sustaining a balanced budget over the cycle and reducing the tax burden. They underscored the importance of quickly designing and setting in motion expenditure measures to reach a structural budget balance.

Financial system. Directors appreciated the resilience of Austria's financial sector, while emphasizing that developments in financial markets require continued close monitoring, particularly regarding the growth of foreign currency loans and the rapidly expanding activities of Austrian financial institutions in CESE. Directors welcomed further strengthening of supervision and interest in an FSAP update.

Structural policies. Directors supported the authorities' focus on structural reforms, including in the area of pensions and labor market, and encouraged them to keep the momentum in implementing these reforms.

${ }^{1}$ The latest Public Information Notice is available at http://www.imf.org/external/np/sec/pn/2007/pn0748.htm.

\section{The ruling grand coalition of social democrats (SPOe) and conservatives (OeVP)} agreed on a new government work program in March 2008. The plans in this broad work program are consistent with the Government Program agreed upon in early 2007, and include reduced social security contributions for low income earners, bringing forward pension increases, pension harmonization at the lower levels of government, freeze of a number of levies collected at the federal and regional level, tax-cuts in 2010, health reform, and administrative reform. The staff report addresses the macroeconomic and structural measures

\footnotetext{
${ }^{1}$ A team comprising Mr. Hilbers (head), Mr. Lundback, Mr. Kanda, Mr. Rosenberg (all EUR) and Mr. Hardy (MCM) visited Vienna during March 7-17, 2008. Austria is an Article VIII country and data provision is adequate for surveillance (see Informational Annex).
} 
in the government program, with a special focus on competitiveness and fiscal and financial sector policies.

\section{RECENT DEVELOPMENTS}

3. The economy grew strongly in $\mathbf{2 0 0 7}$ and through the first quarter of $\mathbf{2 0 0 8}$ (Tables 1 and 2, Figure 1). Real GDP in 2007 grew by 3.4 percent, driven by strong exports and investment, while private consumption growth decelerated. Preliminary estimates for the first quarter of 2008 show continued strength of the economy. However, leading indicators of production, services, and consumption, are off their peaks and the growth momentum is expected to soften as economic activity in trading partners dampens (Figure 2).

\section{Employment growth remains strong, but the trend of a declining unemployment} rate appears to be tapering off. As economic activity has picked up in recent years, employment growth has accelerated strongly to reach high levels (Figure 3). The effect on the unemployment rate has been moderate, although this rate (4.1 percent in April) remains significantly lower than in the euro area. The relative unresponsiveness of unemployment to employment growth can partly be explained by an influx of foreign workers into Austria.

\section{Tighter labor market conditions have not resulted in sharp wage increases, but} negotiated wages for $\mathbf{2 0 0 8}$ are up. In the past few years social partners have been able to agree on moderate wage increases (Figure 4). This reflects stronger international competition through both trade and increased inflows of migrant workers. As a result, unit labor costs have been contained and compare favorably with the rest of the euro area. Negotiations for 2008 resulted in a $3 \frac{1}{2}$ percent wage increase for industry workers, which exceeds outcomes in recent years.

\section{Austria's external position remains strong, despite a recent decline in}

competitiveness. The current account turned positive in 2002 and has remained strong on account of strongly growing exports (Table 3 ). This reflects a period of wage moderation combined with robust productivity growth, resulting in strengthened competitiveness (Figure 5). In the last year, the ULC based REER has started to edge up again, but it still compares favorably with the euro area. Meanwhile, the world market export share has improved somewhat, although it is still below the levels in 2004-05. CGER calculations indicate that Austria's real exchange rate is around its long-run equilibrium. ${ }^{2}$

7. Headline inflation jumped in late 2007 due to sharp increases in energy and food prices. Headline inflation was 3.4 percent, year-on-year, in April 2008. Core inflation,

\footnotetext{
${ }^{2}$ The macro balance approach indicates a 3 percent undervaluation and the external sustainability approach a 6 percent undervaluation, while the equilibrium real exchange rate approach points to a 7 percent overvaluation.
} 
Figure 1. Austria: GDP Growth, 2002-07
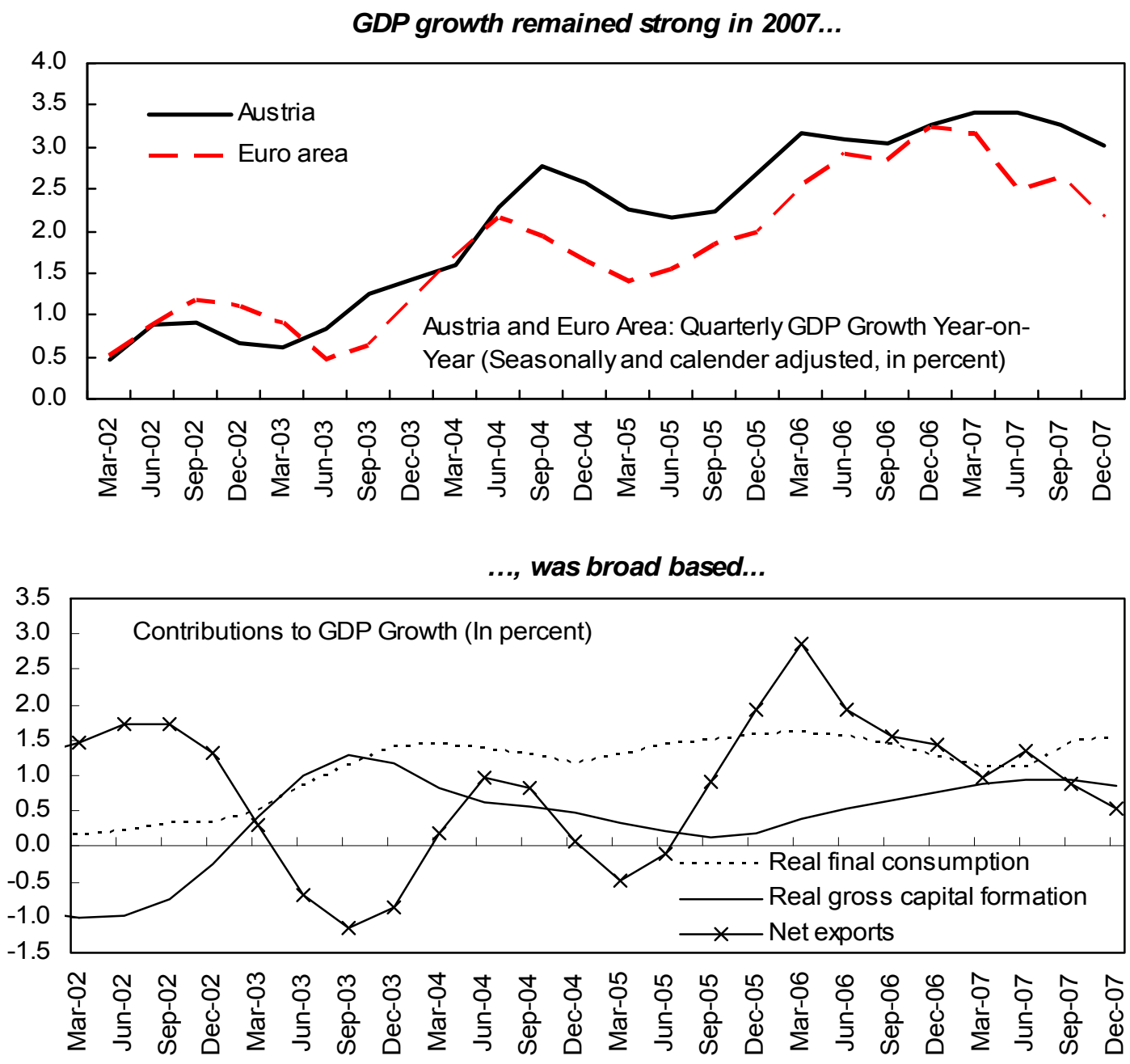

...and the output gap turned positive.

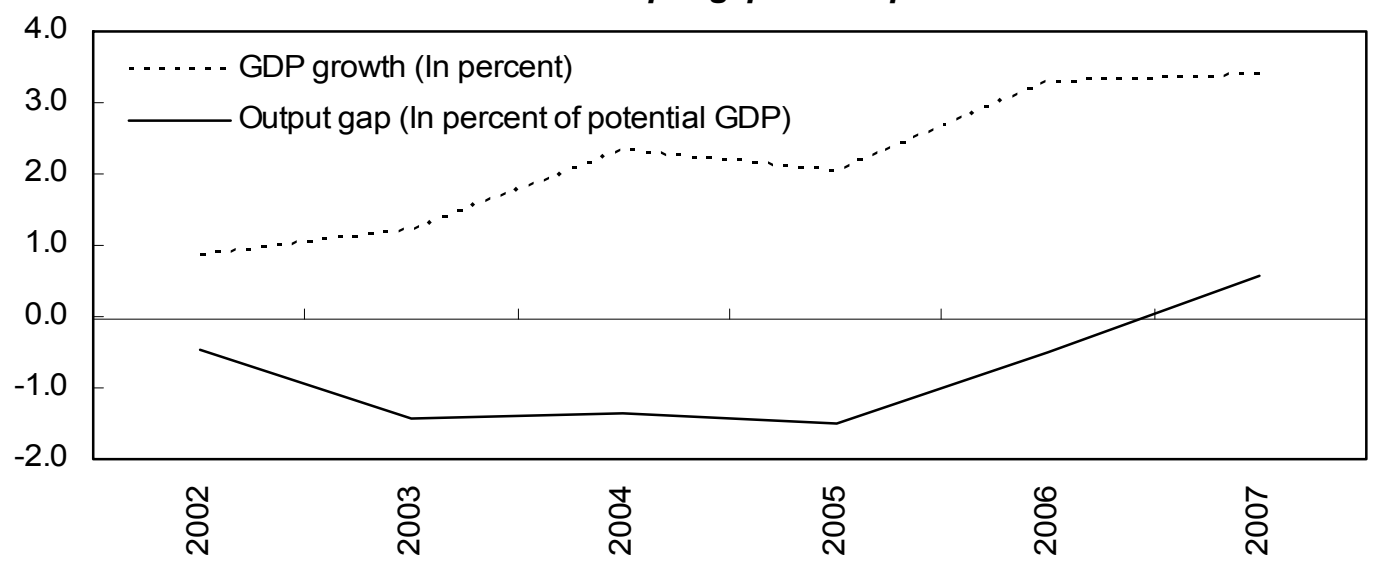

Sources: Austria Statistical Office; and IMF staff estimates. 
Figure 2. Austria: Leading Indicators, 2002-2008

Manufacturing...

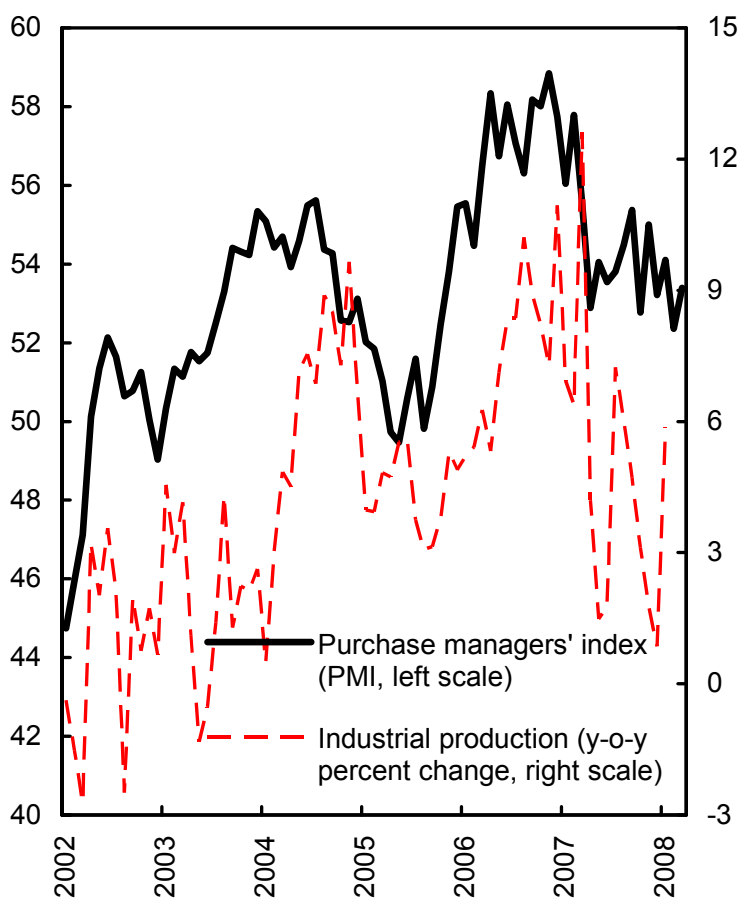

...consumer and...

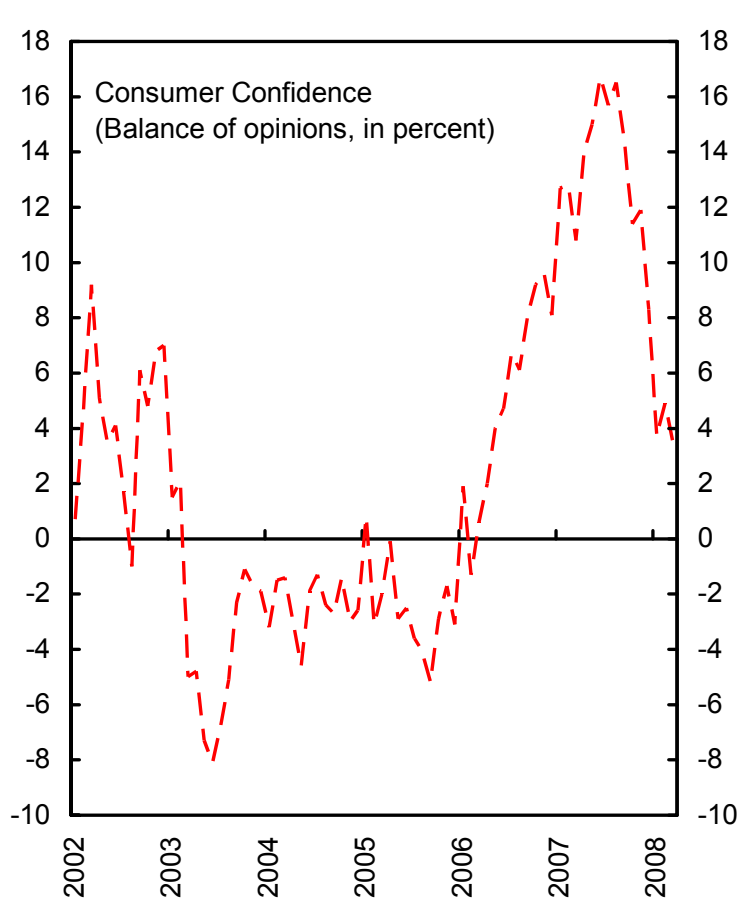

Source: OeNB. ...service...

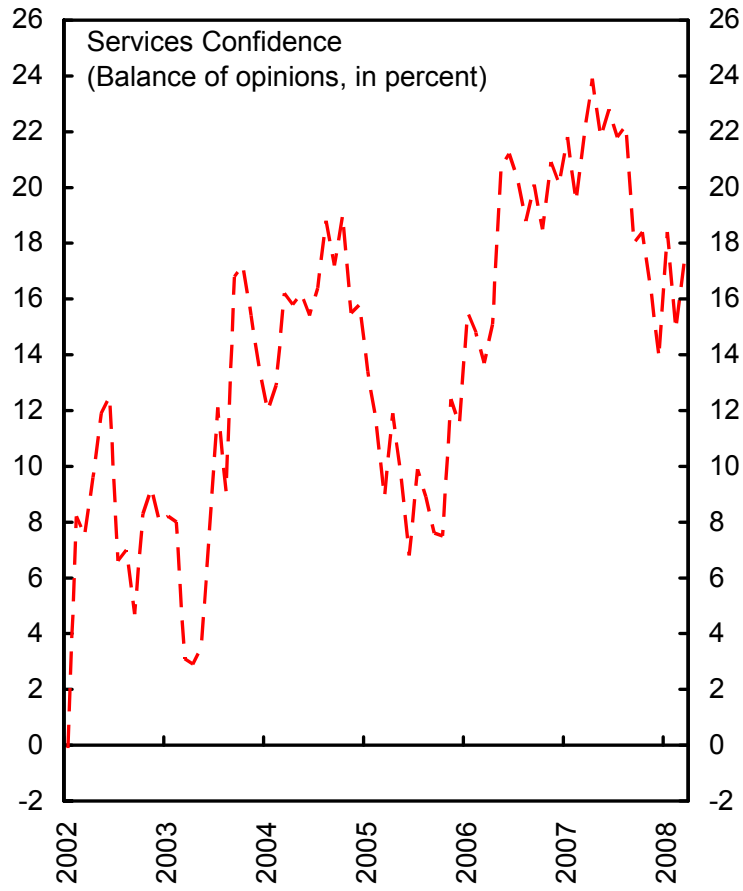

...retail confidence are down from earlier peaks.

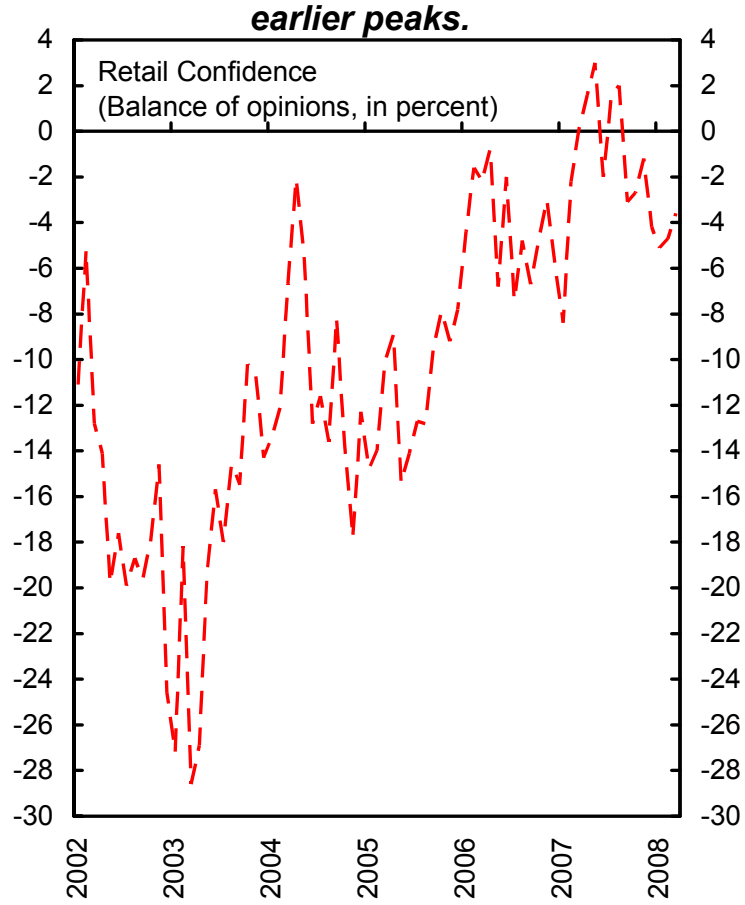


Figure 3. Austria: Labor Markets, 2002-07
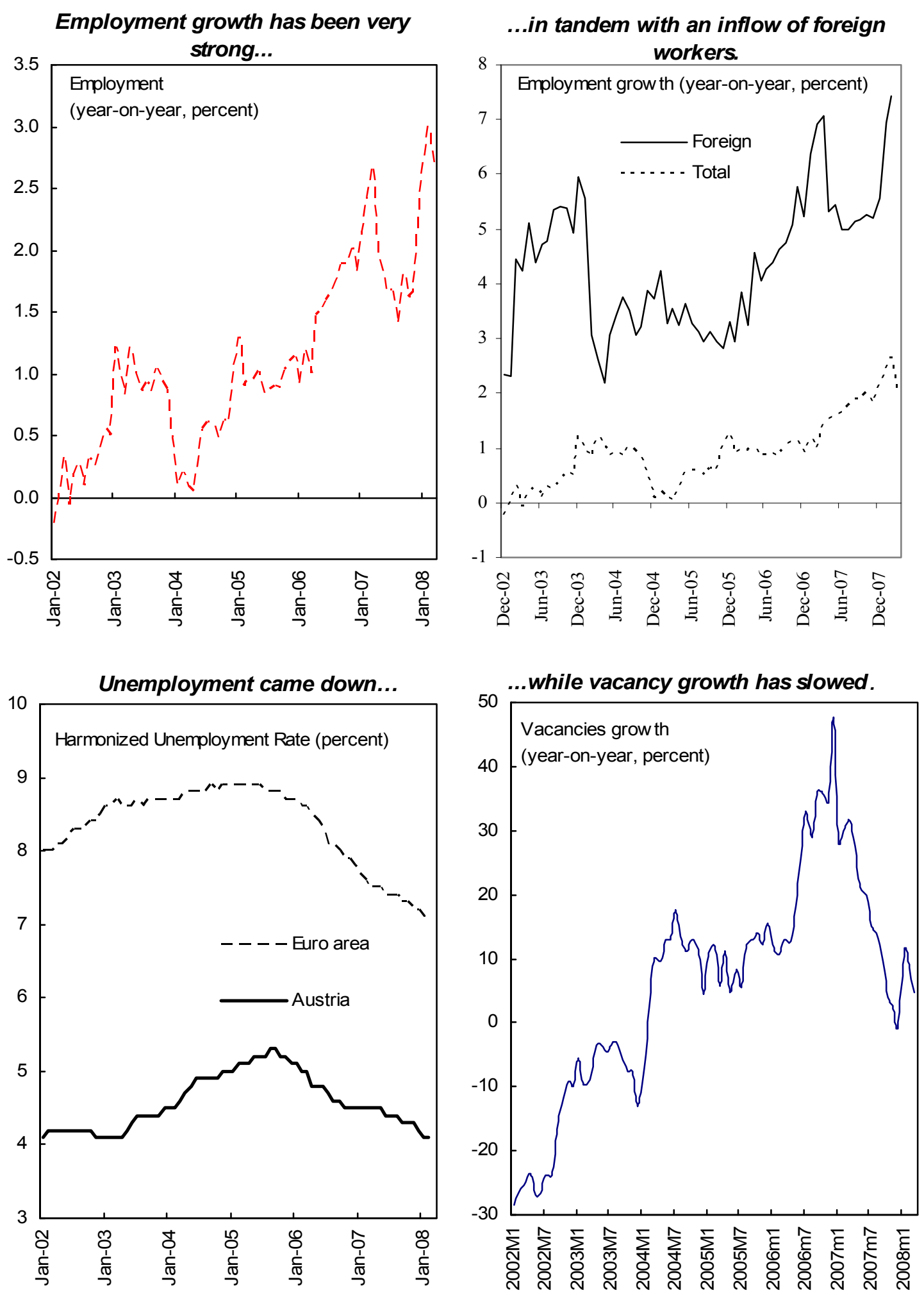

Sources: OeNB; and Fund staff calculations. 
Figure 4. Austria: Wages, 2002-08

Negotiated wage increases have been relatively modest, limiting real wages..
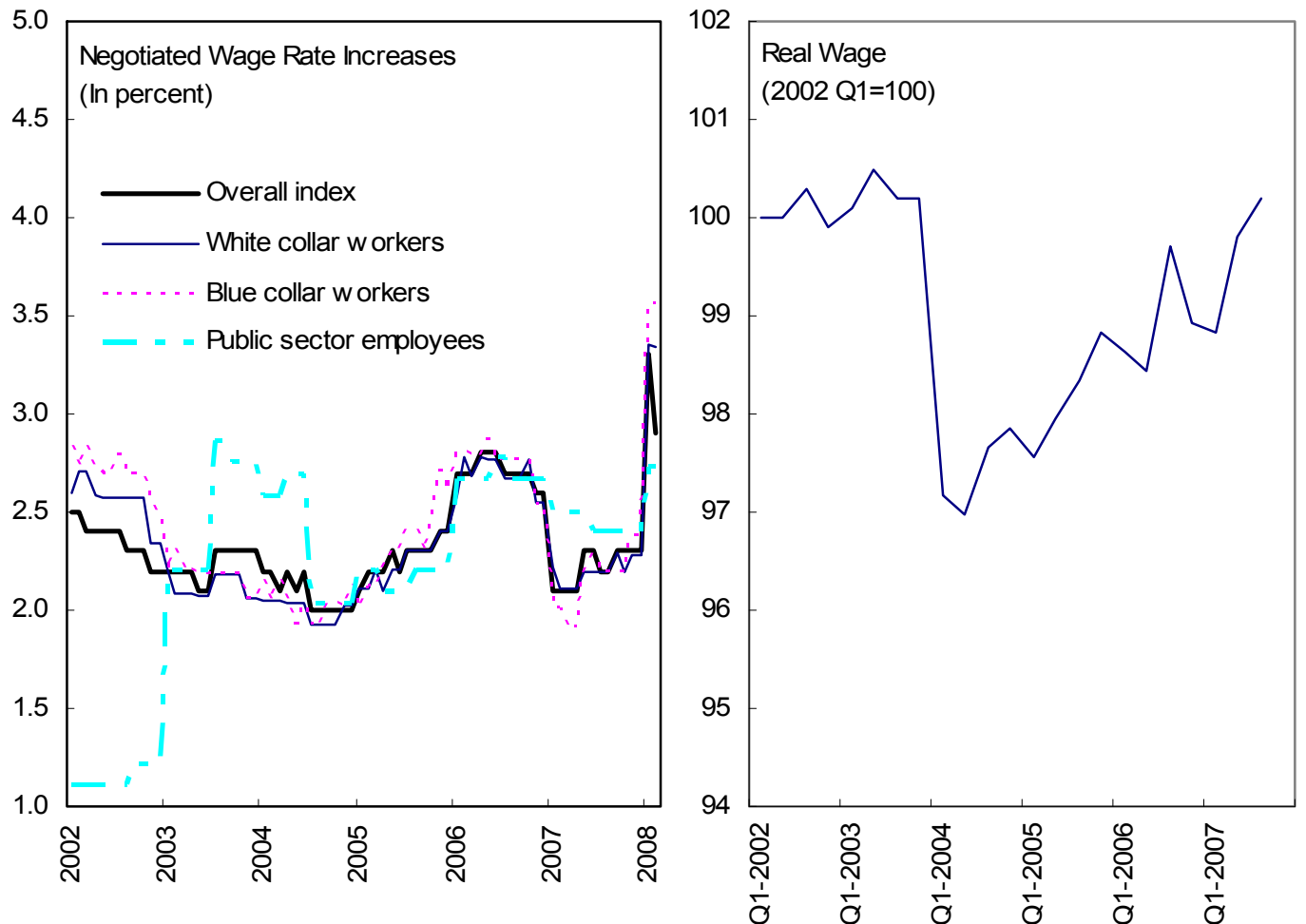

....and keeping Austria comparing favorably to its peers.
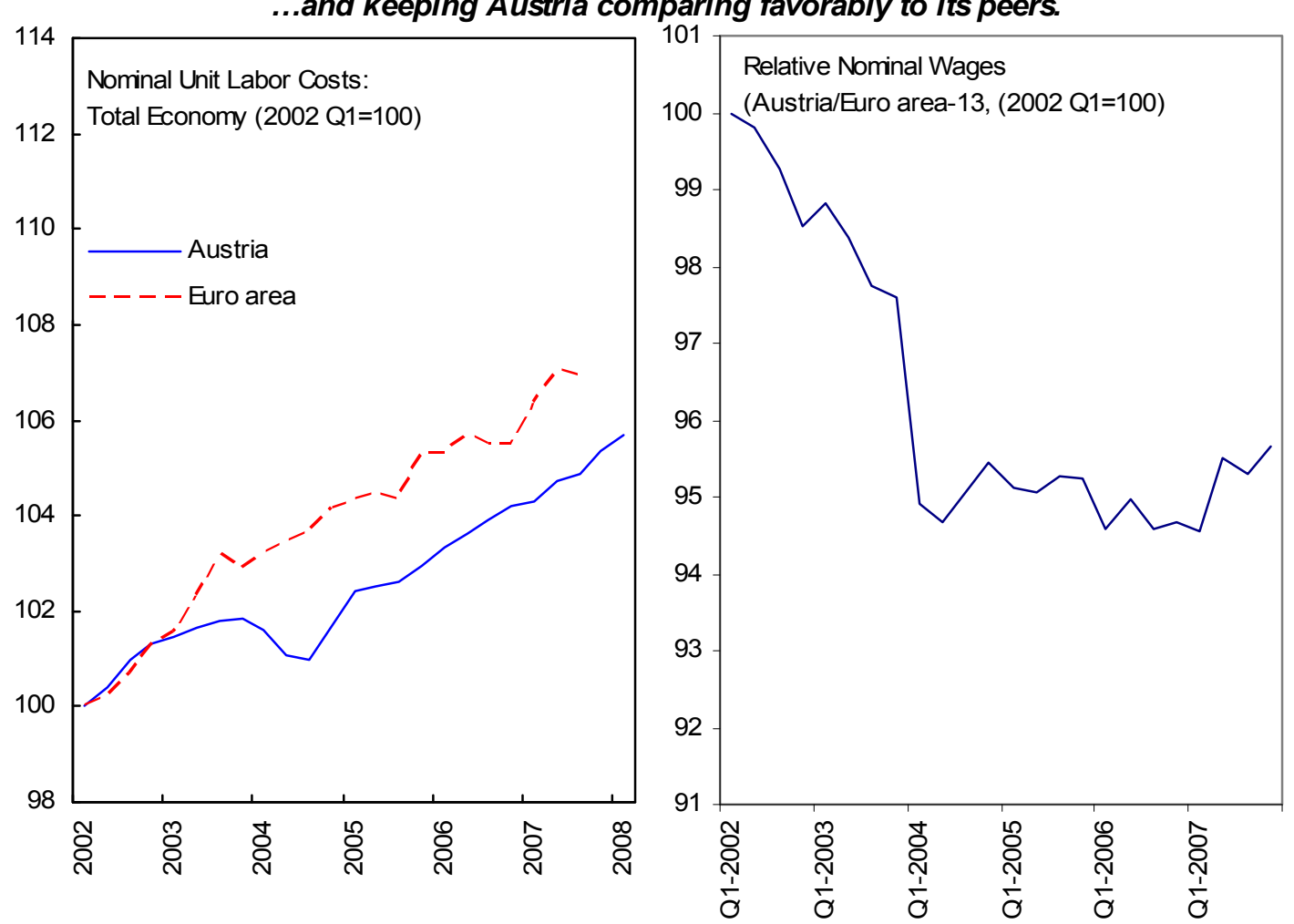

Source: Eurostat. 
Figure 5. Austria: Competitiveness, 2001-08

Market shares rebounded...

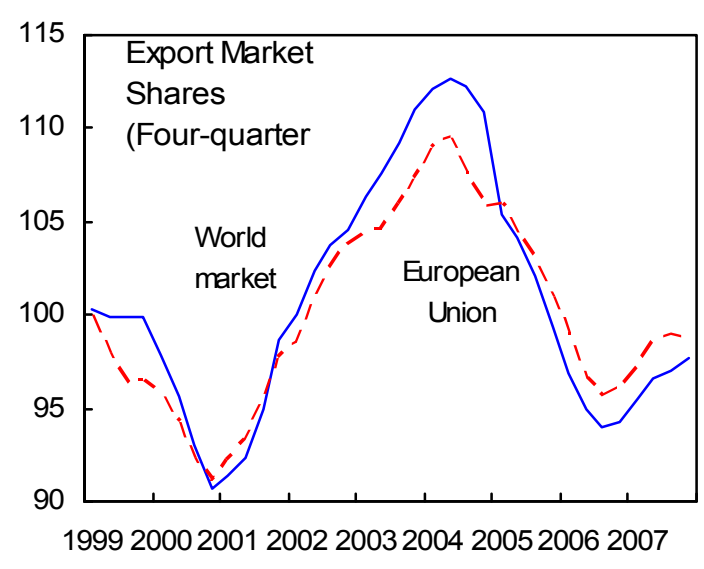

Productivity growth is holding up...

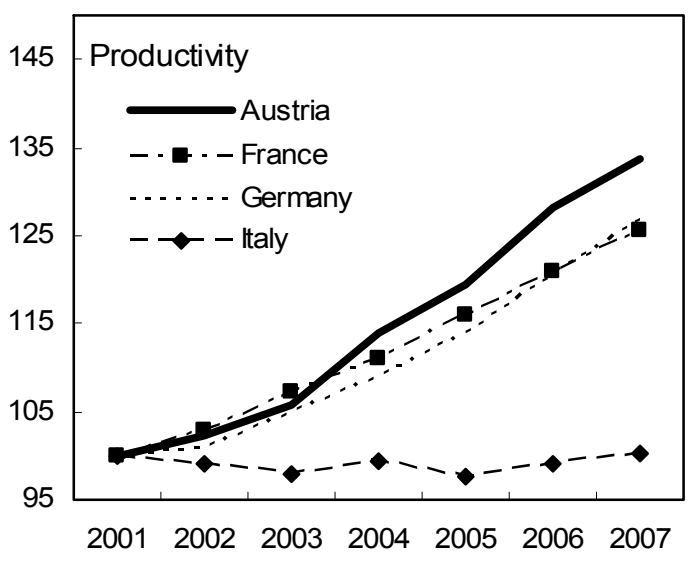

...despite some REER appreciation.

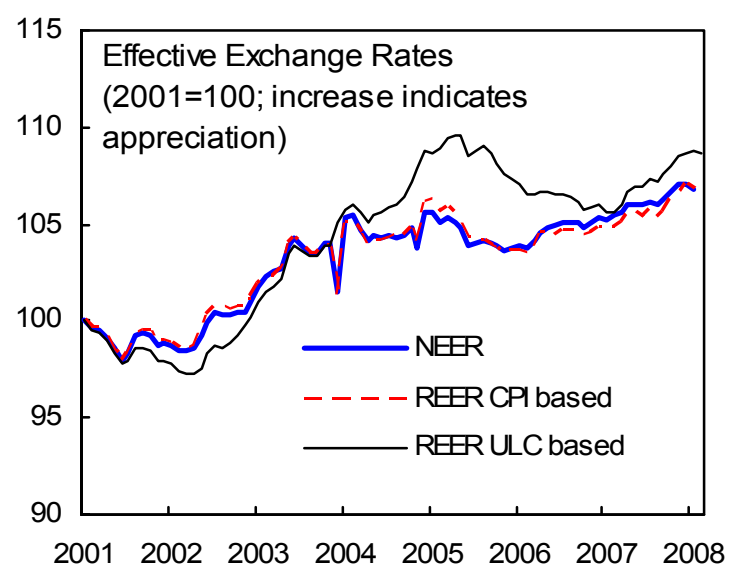

....and competitiveness developing better than in the euro area...

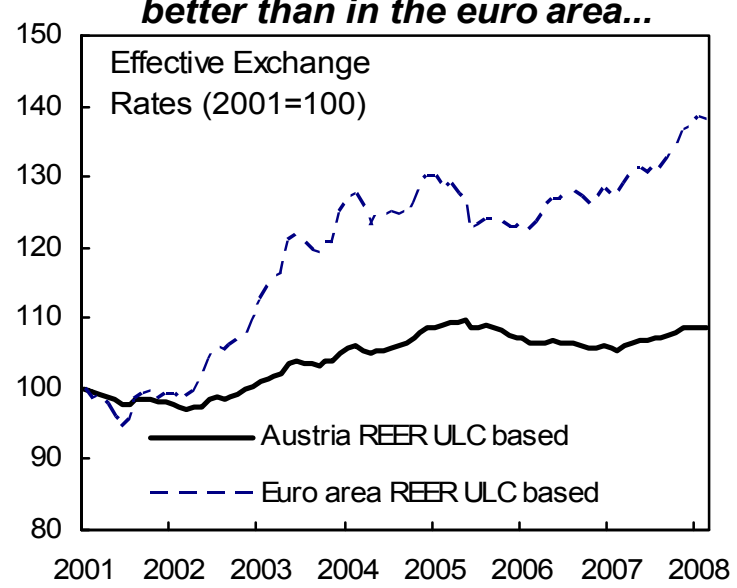

...resulting in an improving current account and continued strong export growth.
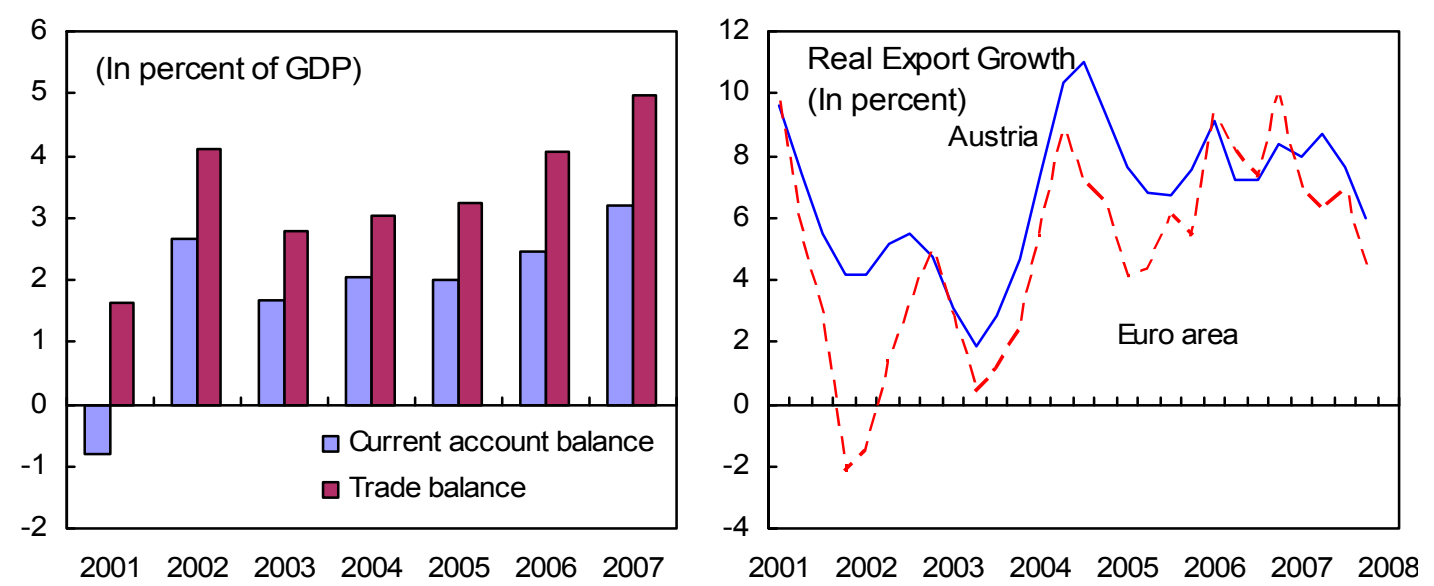

Sources: OeNB; World Integrated Trade System; Eurostat; and IMF staff calculations. 
excluding energy, food, alcohol, and tobacco, has been contained and now stands at around 1.6 percent. Thus far, there is little indication of wages driving up inflation, and services inflation was only 1.6 percent in April (Figure 6).

\section{The general government fiscal deficit narrowed significantly in 2007 , but the} structural deficit remains high (Table 4). There was a 1 percentage point of GDP improvement compared to 2006, but this number needs to be interpreted with caution. The structural deficit remains large (Figure 7). The authorities' goal of balance over the cycle remains a challenge and Austria's performance is falling behind its EU-15 peers (Figure 8). Tax cuts in recent years have not been offset by corresponding expenditure measures. The outcome for lower level governments is still uncertain as the data have been prone to revisions in the past.

9. Progress in reforming the fiscal federal system has been limited. A new revenue sharing agreement ("Finanzausgleich") between the federal and lower level governments, covering 2008-13, was reached in October 2007. The intergovernmental transfer system was simplified by converting most federal transfers into fixed unconditional shares of the joint revenues collected at the federal level. However, the weak tax autonomy at the sub-national level was not addressed. Also, with effect from 2011 the agreement increases the revenue shares of small municipalities (with less than 10,000 inhabitants) at the expense of the larger municipalities, which would reduce incentives for municipalities to merge and generate economies of scale.

10. The recent financial market turmoil does not appear to have had a major shortterm impact on Austrian banks, but has increased funding costs. Banks' exposures to affected asset classes, including off-balance sheet risks, are reported to be small. The three largest Austrian banks have all reported strong 2007 results and limited write downs. Stock prices of listed major Austrian banks' fell in early 2008, to some extent reflecting their exposure to CESE and CIS countries, but have since rebounded somewhat (Figure 9). Overall, financial sector soundness indicators point to a resilient Austrian banking sector (Table 5).

11. Austrian banks' exposure to CESE has increased significantly. The expansion of financial institutions in CESE, and further east, has continued and Austrian exposures there, at 60 percent of GDP, are larger than those of European peers. In 2006, the total assets of the six largest Austrian banks in the CESE region were equivalent to around 20 percent of total banking assets, and generated almost 40 percent of banks' profits. However, concerns that Austrian parent banks would squeeze their funding of CESE activities in response to the global financial turmoil have so far not materialized. Banks generally have access to ample retail deposits, and they report that the supply of financing through private placements and the issue of Pfandbriefe (a form of covered bond) has held up well. 
Figure 6. Austria: Inflation, 2002-08

The recent jump in inflation was driven primarily by food and energy prices.
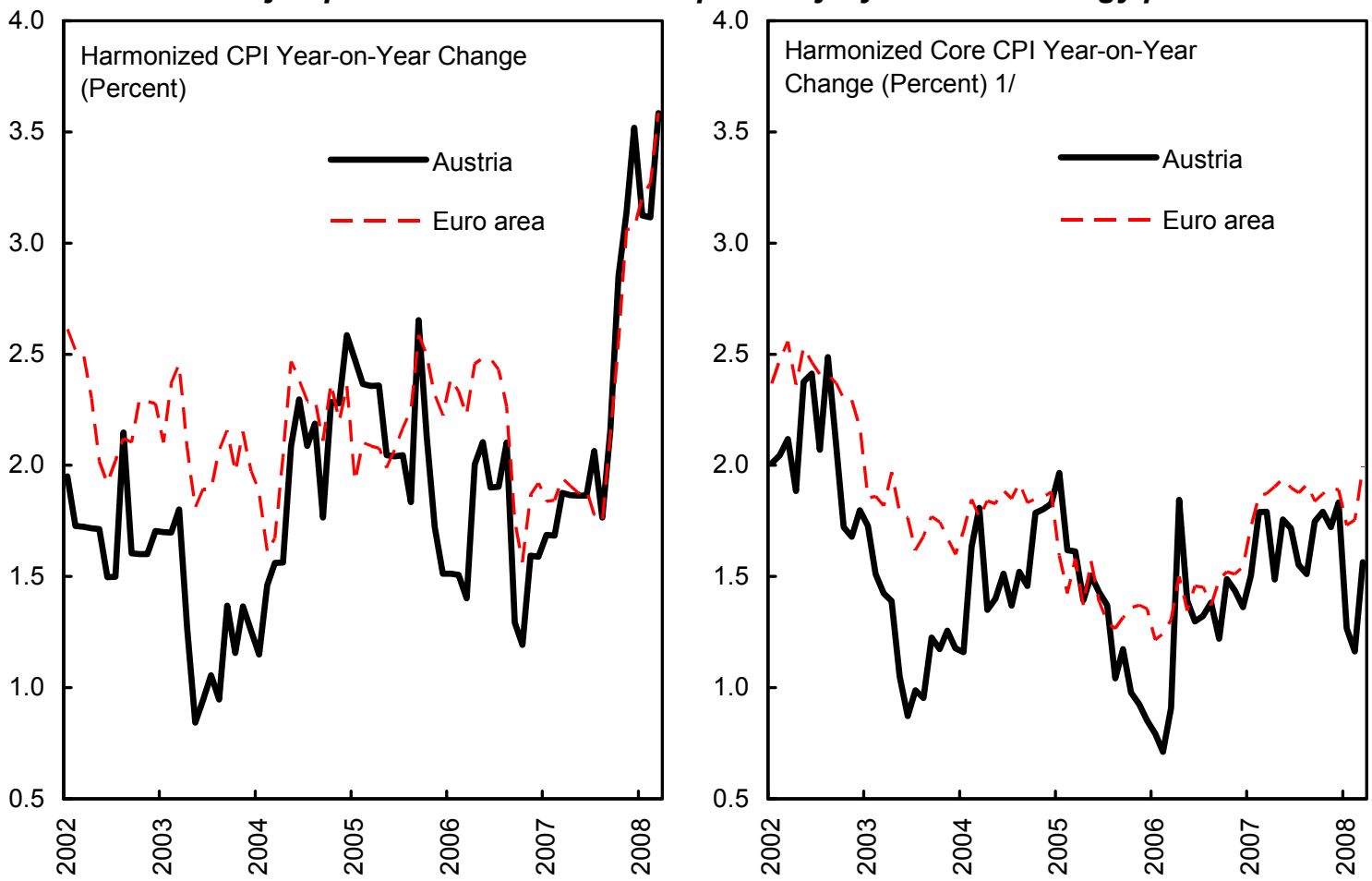

No clear indications of second round effects so far.
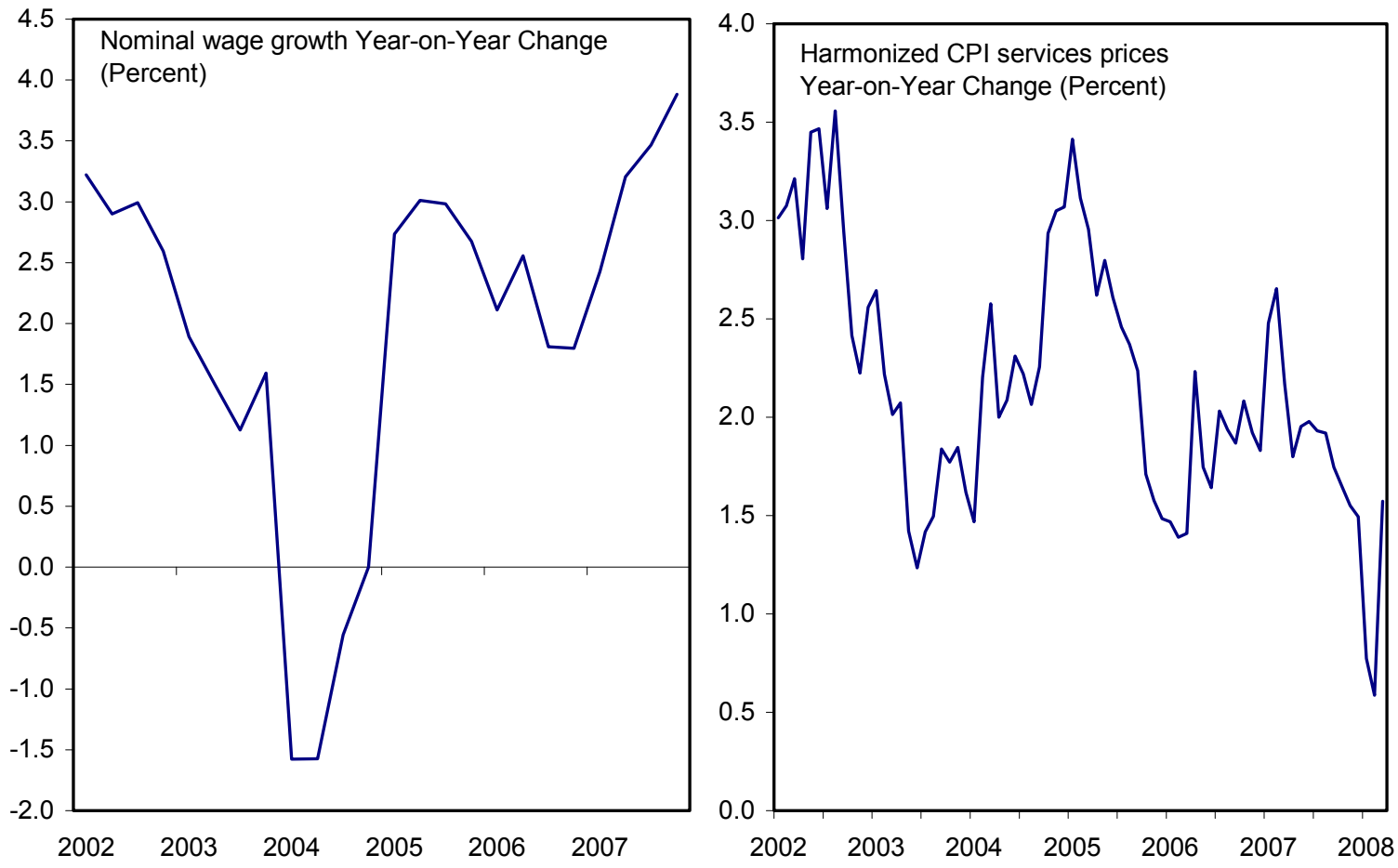

Sources: Eurostat and Fund staff calculations.

1/ Excluding energy, food, alcohol, and tobacco. 
Figure 7. Austria: Recent Fiscal Developments, 2001-2007 1/

(In percent of GDP, unless otherwise indicated)

Tax cuts implied less revenue...
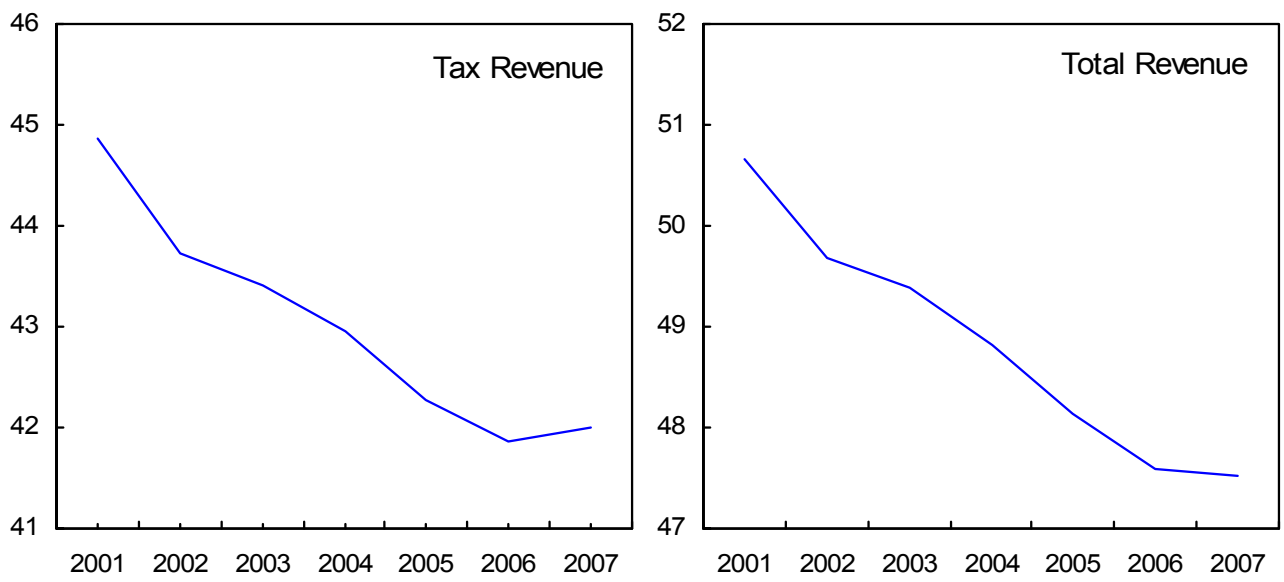

...which, without corresponding expenditure cuts, has led to persistant deficits...
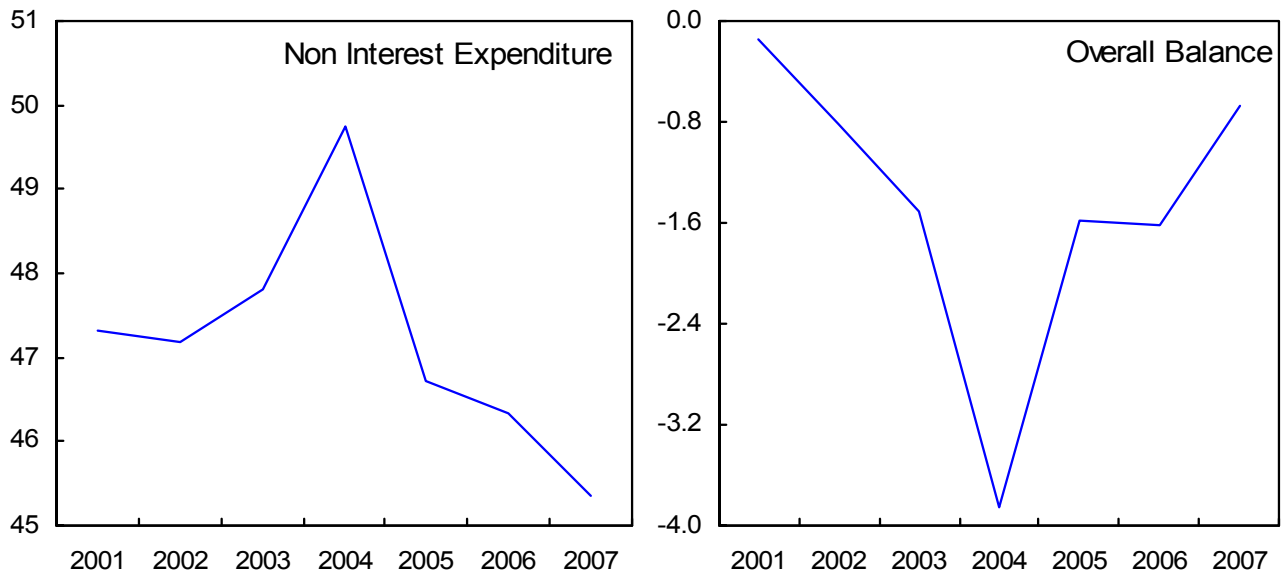

...despite a period of strong economic growth. The structural deficit remains.
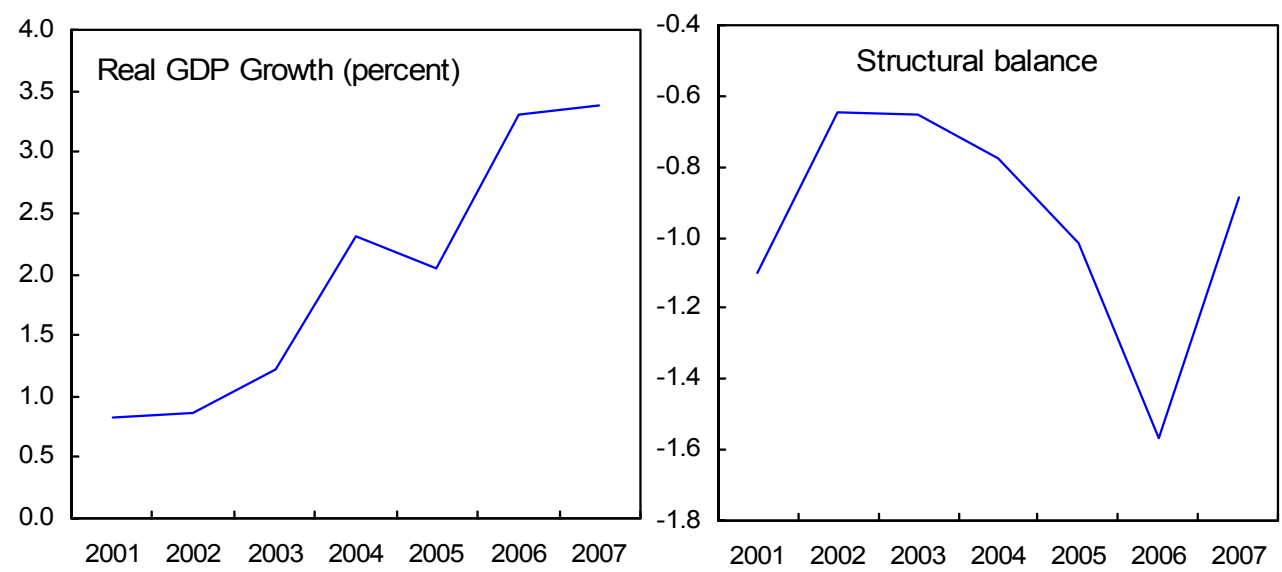

Sources: Austria Ministry of Finance and Staff calculations.

1/ 2004 expenditures were recently revised to include a one-off capital transfer to the Austrian Railways amounting to $2 \frac{1}{2}$ percent of GDP. 
Figure 8. Austria: Fiscal Trend Comparisons, 1997-2007

(In percent of GDP, unless otherwise indicated)
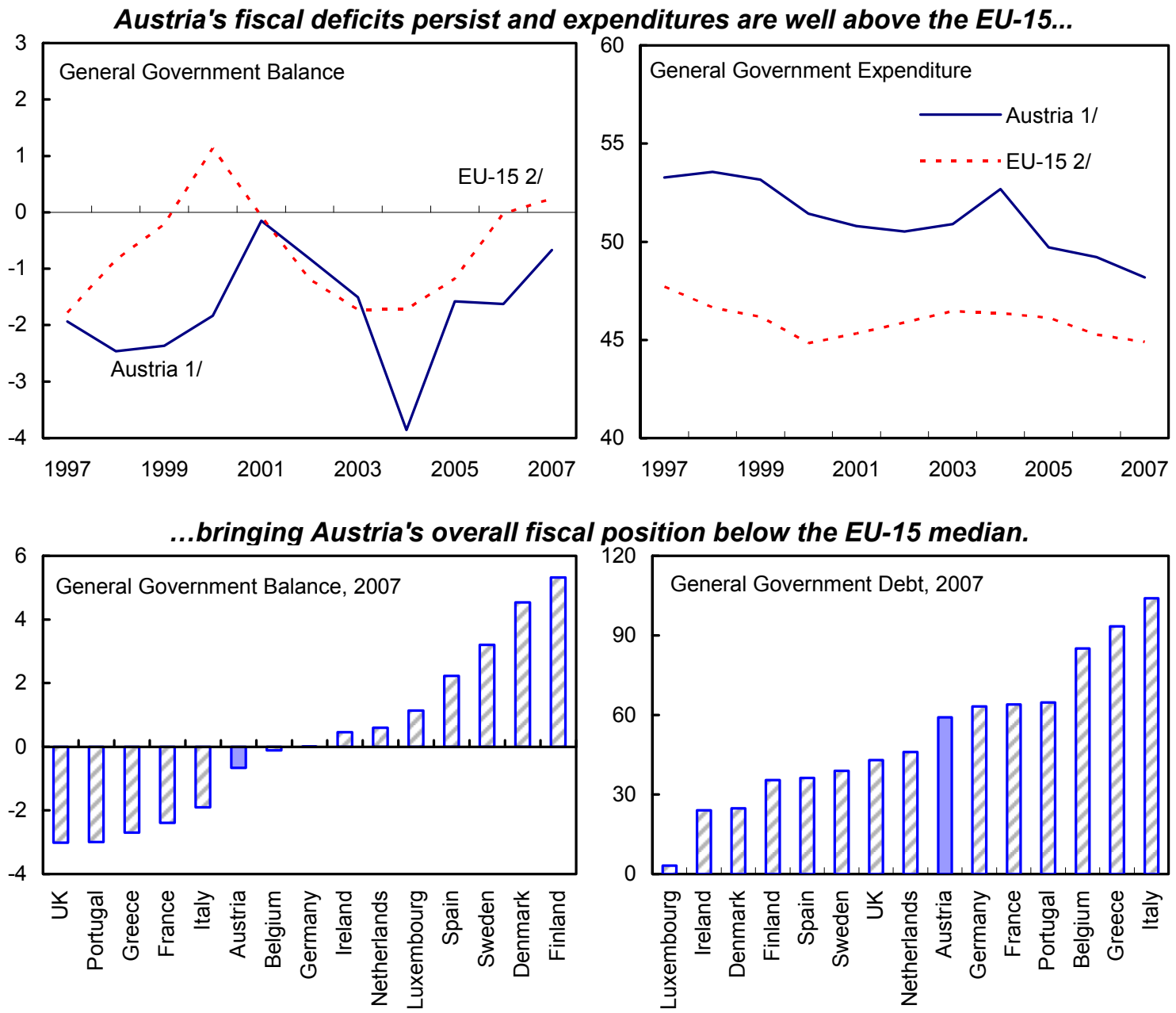

Austria's debt level is now below 60 percent, and the interest spread is small.
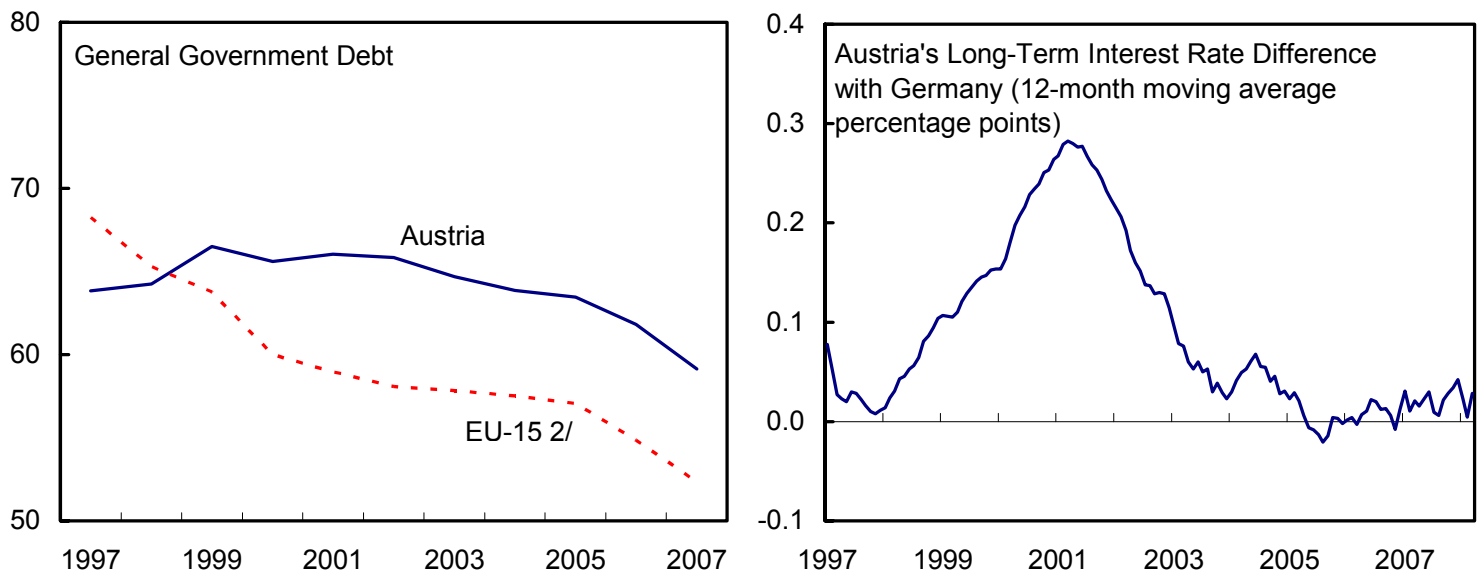

Sources: IMF, IFS ; and WEO.

1/ 2004 expenditures were recently revised to include a one-off capital transfer to the

Austrian Railways amounting to $2 \frac{1}{2}$ percent of GDP.

2/ Unweighted average. 
Figure 9. Austria: Financial Market Indicators, 2007-08
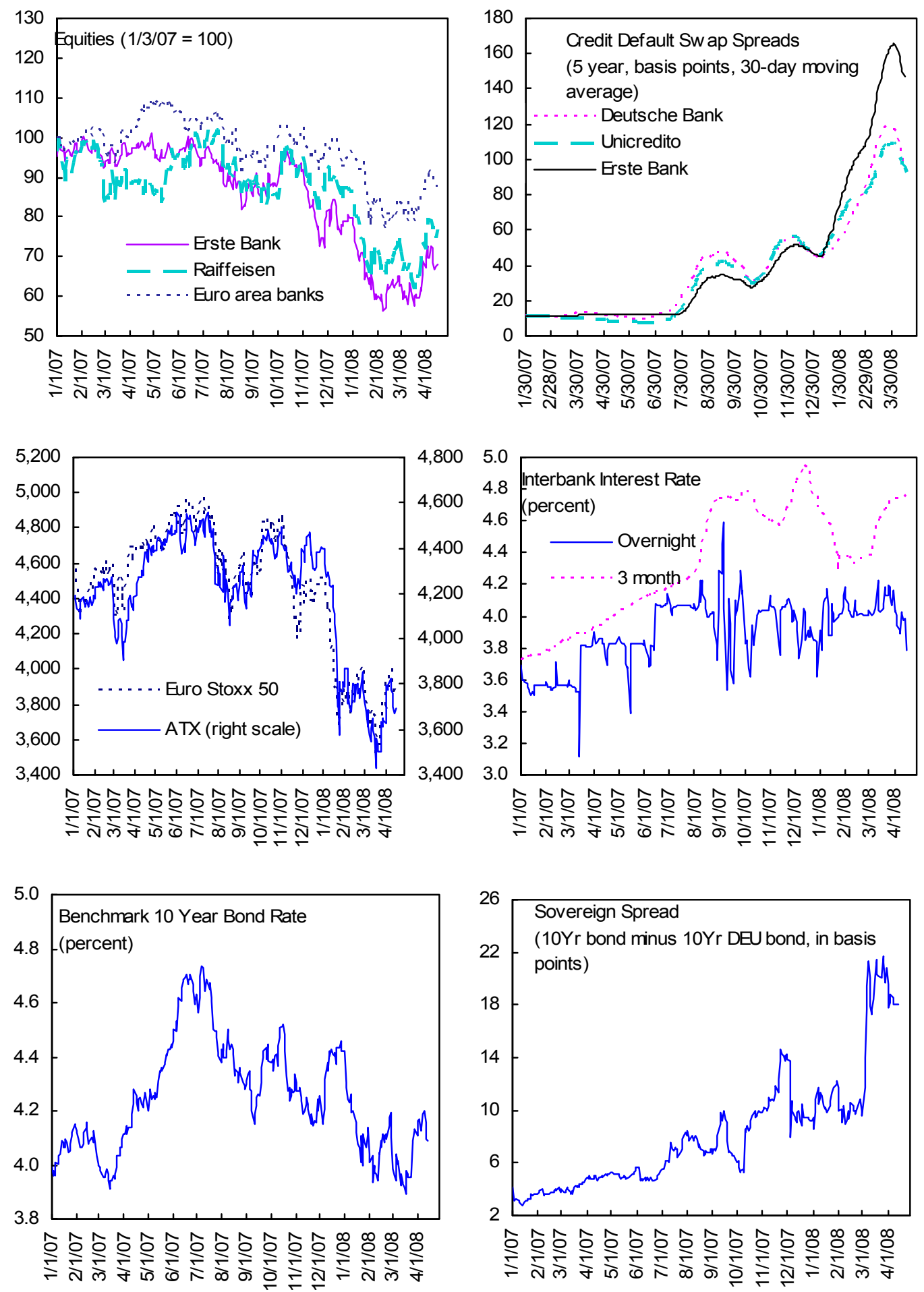

Sources: Thomson Financial/DataStream and Bloomberg. 
12. Higher interest rates have tightened monetary conditions somewhat (Figure 10). Austrian short-term interest rates have risen with the rest of the euro area. Long term rates have risen as well, and the spread over German Bunds has edged up. Overall credit growth to non-banks decelerated slightly in 2007 to 3.4 percent year-on-year by end-year. Household credit growth accelerated by about 2 percentage points to 5.9 percent. Loans in foreign exchange (mainly Swiss francs) remained important, but their share in total loans declined to about $16 \frac{1}{2}$ percent, down by about 4 percentage points from the peak.

13. Past difficulties in individual institutions, where internal controls failed to contain management errors and abuses, prompted an adjustment of the bank regulatory framework, with an enhanced role for the OeNB. Although the FMA retains overall responsibility (and in particular responsibility for regulation and enforcement), besides its responsibilities in the nonbank area, banking inspection and analysis will now wholly be assigned to the OeNB. Important measures have also been taken or are being taken to strengthen corporate governance, including requiring a "fit and proper" test for the chairman of the supervisory board and strengthened internal audit provisions.

\section{REPORT ON THE DISCUSSIONS}

14. Discussions were guided by the 2007 Surveillance Decision. As Austria is member of a currency union, the focus was on five distinct but related areas central to maintaining competitiveness and domestic stability:

- $\quad$ The risks to the short-term outlook, especially if global financial troubles were to deepen and prolong the economic downturn.

- $\quad$ Competitiveness, wages, and inflation, and in particular the role of wage moderation in maintaining competitiveness.

- Near- and medium-term fiscal policies, including fiscal sustainability, and the fiscal stance.

- $\quad$ Reform of federal and lower level government financial relations to enhance the efficiency of public spending.

- $\quad$ Financial sector stability, and the findings and recommendations of the December 2007 FSAP Update.

\section{A. Short-Term Outlook and Risks}

15. After two years of strong growth, a slowdown is now expected. Staff expects growth to drop to around 2 percent in 2008-09, reflecting developments in major trading partners. Private consumption growth in Austria is expected to hold up at current modest levels, while growth in exports and investment is expected to come down due to an 
Figure 10. Austria: Monetary Developments, 1997-2008

Short- and long-term interest rates are up from their lows a few years ago.
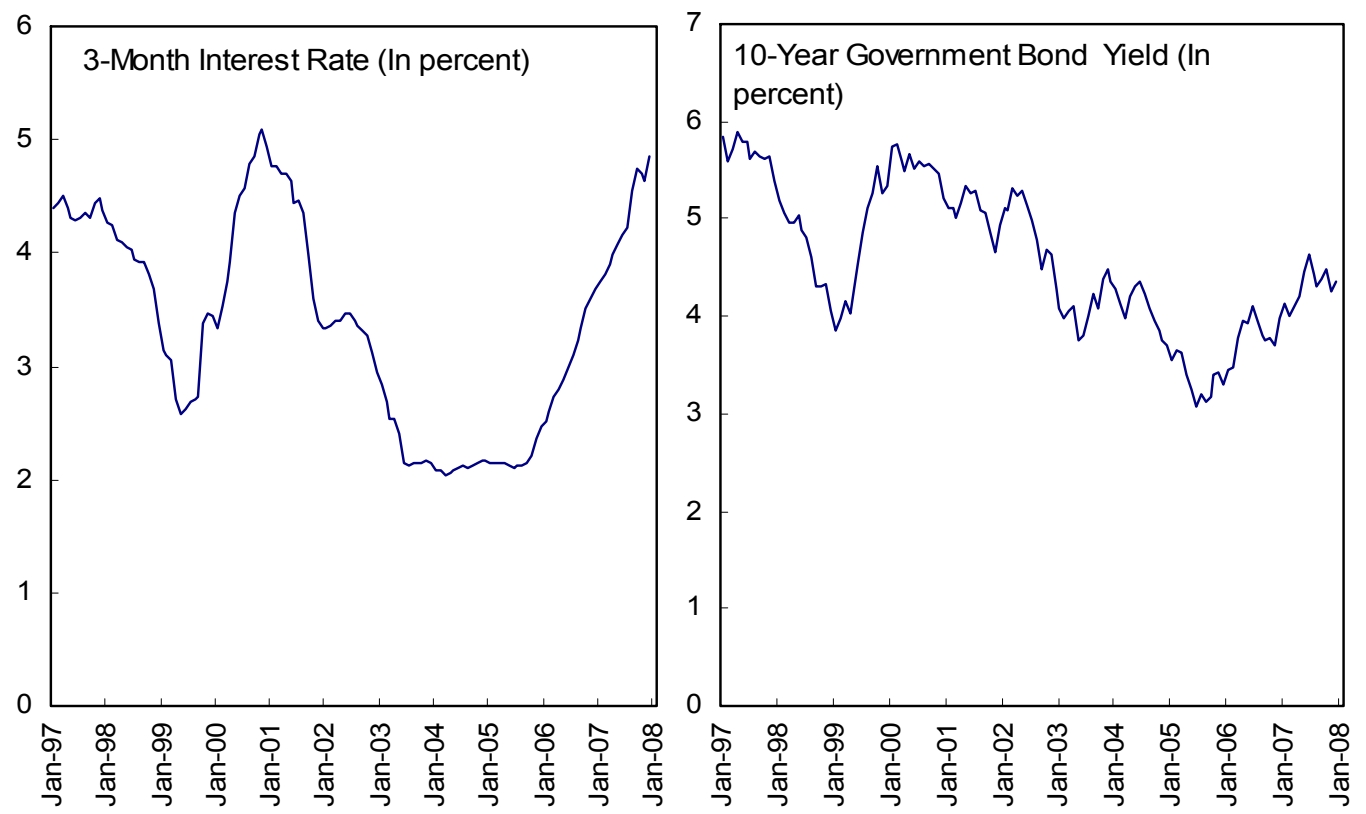

While credit growth has decelerated..

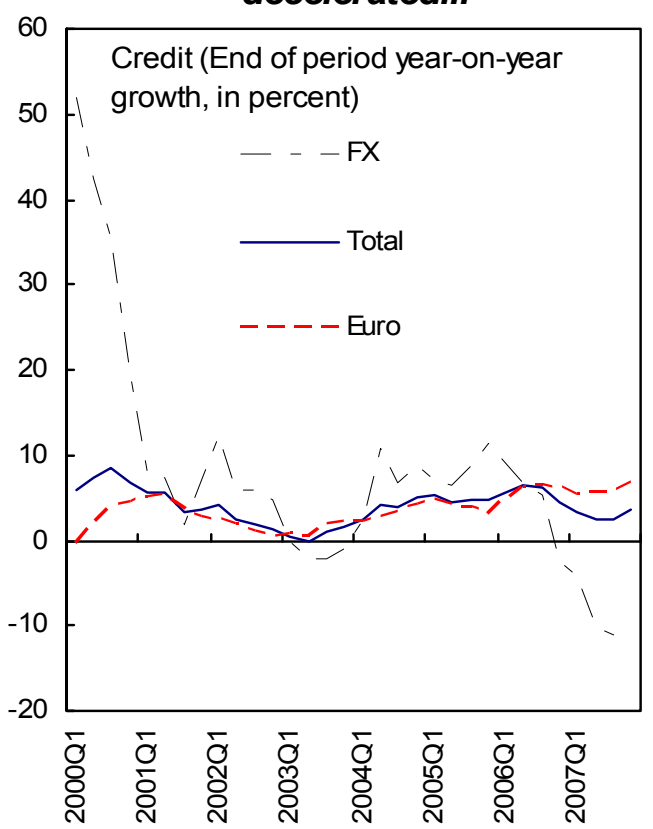

...and monetary conditions have tightened.

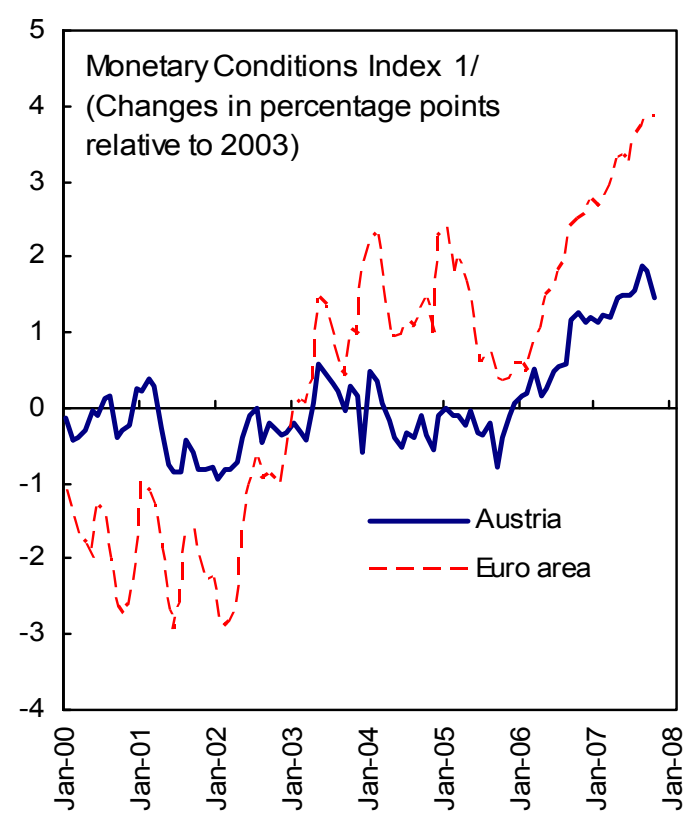

Sources: OeNB; IMF, IFS; ECB; and Eurostat.

$1 /$ Weighted average of changes in interest and exchange rates relative to their average values in a base period. An increase (decrease) indicates a monetary tightening (loosening). 
unfavorable international environment and tighter financial conditions. The authorities were slightly more optimistic as economic indicators so far have been relatively strong. Notably, employment growth had accelerated, boosted by favorable weather conditions for both construction and tourism. They also noted that Austria is more structurally flexible than the European average, and is oriented towards the fast growing eastern European countries, which has so far served as a cushion for Austrian exports.

\section{It was agreed that the impact of the global financial turmoil and the expected} economic downturn on Austria constitutes a risk to the outlook. Thus far, there are few discernable direct real effects on the Austrian economy from the international financial turbulence and repricing of risks. Over time, though, tighter lending conditions and lowered expectations about the future are expected to have an impact, including on the countries that are Austria's main export markets and investment destinations. Private consumption growth could be affected by decelerating employment growth and real wages eroded by sustained high inflation. At the same time, consumption growth has already been quite low through 2007, despite a strong economy. Investment is naturally sensitive to relatively small changes in economic developments and prospects. The euro exchange rate constitutes an additional risk.

\section{B. Competitiveness, Wages, and Inflation}

17. Continued wage moderation would be essential to preserve competitiveness. The authorities stressed that social partners had been responsible in past years. This trend was expected to carry on as there is still a strong consensus regarding the need for wage moderation. Recent negotiated wage increases had in fact been moderate, although higher than in recent years, and there were few signs of a wage-price spiral in current wage data. However, there was agreement on the need for continued vigilance, as the recent jump in consumer price inflation could still prompt elevated wage demands in coming negotiations, fueling second round inflation effects.

18. The authorities were concerned about the recent jump in inflation and saw this as an argument to step up structural policy implementation. They were in particular considering measures to open up markets for competition, including in the energy sector and in the free professions. The mission supported such measures as they promote efficiency gains and may lead to lower prices, but cautioned that the effect on inflation would likely be limited and lagged. In this context, the mission noted that the resources and investigative powers of the Federal Competition Authority could be further enhanced, and urged the authorities to fully implement the EU directive on services.

\section{The authorities argued that the labor market is quite flexible, and recent} reforms have made it even more so. Reforms include increased working time flexibility, reform of the severance payment system, longer shop opening hours, and the introduction of unemployment benefits for self employed persons. Pension reforms, when implemented as 
planned, would encourage labor market participation of older workers, while also contributing to long-run fiscal sustainability. Furthermore, it was agreed that coming tax cuts should focus on labor taxes in order to boost employment and competitiveness.

\section{Fiscal Policy}

\section{The authorities reaffirmed the objective of a structurally balanced budget by}

2010. A balance over the cycle is required to: (i) ensure fiscal sustainability as pressures from aging rise in the medium and long term, in particular on health, care and pension expenditures; (ii) keep public debt on a downward path from its current level of just below 60 percent of GDP, which also reduces interest costs; and (iii) meet Stability and Growth Pact commitments.

21. However, reaching that target appears challenging. In 2007, the general government was still in deficit at what seems to be the peak of the business cycle and the structural deficit was around 1 percent of GDP. The 2008 budget implies limited improvement, and the government recently proposed to bring forward increases in pensions and to reduce social security contributions for low-income households within the context of the revamped government work plan. This pushes most of the required consolidation to 2009 and 2010. Furthermore, tax-cuts in the order of 1 percent of GDP are planned to be implemented by 2010 . Thus, structural balance by 2010 would require measures to the tune of about 2 percent of GDP. In addition there are plans to implement major infrastructure projects through public companies, which raises the prospect of a substantial increase in the contingent liabilities of the government. The authorities agreed that the needed consolidation would be challenging. At the same time they were more optimistic about economic growth and the underlying strength of revenues, and emphasized the government's commitment to a structurally balanced budget by 2010 .

22. Most of the needed improvement will have to come through expenditure savings. In addition, over the medium to long-term more would be needed to offset aging pressures. Studies point to a risk of substantial long run increases in pension and health expenditure, despite recent reforms. ${ }^{3}$ The authorities noted that they have embarked on a reform of the health system, which should generate efficiency gains.

23. The adoption of a medium-term budgetary framework was welcomed. Forceful implementation paired with transparency would be key to establish credibility. ${ }^{4}$ For the new

\footnotetext{
${ }^{3}$ See OECD, Economic Survey Austria, 2007; and Daniel Kanda, "Long-Run Fiscal Challenges in Austria," IMF Country Report No. 07/143.

${ }^{4}$ Erik Lundback, "A Medium-Term Budgetary Framework-What Can Austria Learn from Other Countries?” IMF Country Report No. 07/143.
} 
framework to be most useful, long term considerations, such as the implications of aging, should be integrated into the framework.

\section{Fiscal Federal Relations}

\section{The authorities and staff agreed on the merits and broad direction of reform of}

fiscal federal relations. Most public sector savings and efficiency gains achieved in recent years have been accomplished at the federal level, with the provincial governments lagging in the implementation of pension and administrative reform and the adoption of a medium term expenditure framework. Achieving major and lasting expenditure savings would require strengthening accountability and incentive structures at the sub-national level (Box 2).

\section{Box 2. Fiscal Federalism in Austria ${ }^{5}$}

Austria's federal system consists of the federal government, 9 provincial governments, and 2,357 municipalities (including cities and towns). The federal parliament consists of two chambers: the Bundesrat with members appointed by the provincial parliaments, and the Nationalrat with directly elected members. Thus, legislative initiatives typically require provincial support to pass. Municipalities vary widely in size: about 1,500 municipalities contain less than 2,000 persons, and there are only 24 municipalities with more than 20,000 persons. Intergovernmental fiscal relations are complex and often opaque, and have generated various incentive problems and inefficient spending. Key characteristics include:

- In several areas - most notably in health and education - closely related and overlapping expenditure tasks are allocated to different levels of government, alongside a variety of co-financing arrangements, blurring the lines of responsibility.

- Low subnational tax autonomy has weakened incentives to contain spending at the sub-national level. Over 90 percent of taxes are collected and regulated at the federal level as joint taxes to be shared with subnational governments.

- The revenue equalization mechanism is complex, with pervasive earmarking of funds. This has generated inefficiencies in the allocation of expenditure and made it very difficult to assess the efficiency of various spending activities.

- Weak disclosure and accounting standards limit public accountability, particularly at the subnational level. For example, parts of health care spending are carried out through a variety of extra budgetary units, with the proportion of such spending that appears on-budget varying considerably across the various subnational governments.

This structure has undermined the accountability of sub-national governments and reduced the efficiency of expenditure. An attempt at constitutional reforms needed to rationalize the system stalled in 2005.

\footnotetext{
${ }^{5}$ Daniel Kanda, "Perspectives on the Reform of Fiscal Federal Relations in Austria," Selected Issues Paper 2008.
} 
25. However, the authorities explained that achieving a broad political consensus on such reform would be difficult. Implementing a new allocation of expenditure responsibilities across different levels of government would require changes to the constitution. Even though the current grand coalition government has a large majority in parliament, agreeing on a constitutional reform, which would also require agreement by lower level governments, would be difficult.

\section{E. Financial Sector}

26. The financial system has benefited from macroeconomic stability at home and profitable growth opportunities in CESE and some CIS countries, which, however, have brought new exposures (Box 3). As documented in the accompanying Financial System Stability Assessment (FSSA) Update, the system and in particular the banks are profitable, well-capitalized, and liquid. Nonetheless, the authorities and the banks themselves noted the challenges of managing a loan book that is expanding rapidly in emerging market countries which have no recent experience of a conventional business downturn and where competition for market share is intensifying. Certain individual banks have relatively concentrated exposures. Stress tests corroborate that managing credit risk in Austria, CESE, and the CIS is the main potential challenge for Austrian banks; a particular concern is the sizable indirect foreign exchange risk through foreign currency lending at home and abroad.

\section{Direct effects of recent global financial turbulence have been modest because} banks have concentrated on originate-and-hold business. The authorities pointed out that the rise in funding costs associated with the recent turmoil may slow credit growth to a more sustainable pace. Staff noted that it may also reveal credit quality problems, notably where macroeconomic imbalances are pronounced, and a major slowdown in the region would likely feed back into the quality of Austrian assets. Higher funding costs and the maturation of CESE financial markets are likely to thin the banks' (currently comfortable) profitability cushions

28. Financial regulation and supervision have become more risk-based. The authorities noted that this would continue, with more frequent on-site supervision and further enhanced off-site analysis, including through stress testing. Given Austria's role as both home and host supervisor, on-going international cooperation is a high priority.

29. The recent reorganization of banking supervision, whereby all inspection and analysis work is assigned to the OeNB while the FMA retains other responsibilities, will require the two institutions to cooperate very closely. The allocation of responsibilities is clearer than before, but any split brings certain risks. Arrangements must be in place to ensure that, even in stress situations, decisive, timely and well-informed action can be taken. The authorities are instituting mechanisms to this end. 


\section{Box 3. Main Recommendations of the FSAP Update}

The FSAP Update recommendations broadly accord with the authorities' own priorities, and they have already taken steps to implement some of them. The main immediate areas for action (which mostly apply to nonbanks as well as banks) are as follows:

Cooperation with foreign home and host supervisors will need to be developed further. The Austrian authorities are active in the various EU-level mechanisms to facilitate supervisory cooperation (and the recent EU-wide Memorandum of Understanding on crisis management enhances some mechanisms, such as the use of supervisory colleges). They also work with supervisors further afield. But more will have to be done as financial systems integrate, for example, through joint analysis, more coordinated inspections, and the conduct of crossborder crisis simulations.

On-site inspections need to be more frequent, and complemented with the use of sophisticated systems for the early detection of potential strains. The traditional reliance on external auditors for much on-site work may not cope well with cross-border financial institutions employing complex techniques and products in fastmoving financial markets. The authorities are going to have to continue to understand banks' evolving risk models, for example, and develop further their understanding of systemic factors, such as the connections between regional macroeconomic performance and financial sector soundness. Supervisors will need resources to achieve all this.

The OeNB and the FMA will need to be fully and publicly committed to intense cooperation in banking sector oversight. Steps are already being taken to operationalize this cooperation, for example, through the establishment of a common database. Protocols for dealing with problem cases will need to be developed.

The supervisors should ensure that banks continue to manage indirect credit risk stemming from foreign currency loans and promote borrowers' awareness of the risks. There are considerable indirect credit risks associated with foreign currency lending, both domestically and abroad.

Government institutional liability for financial sector supervision should be defined more narrowly. Under current provisions, the failure of a financial institution generates numerous court cases claiming damages from government for negligence in supervision. Taxpayers bear a heavy cost, supervisors are distracted from their normal duties, and moral hazard may be engendered.

The state-sponsored pension scheme (Zukunftsvorsorge) has established itself, so the time has come to loosen some restrictions that apply. For example, the requirement to invest in small stock exchanges, and the mandatory full guarantee of principal should be reconsidered.

\section{Staff ApPraisal}

30. In line with developments in major trading partners, a slowdown is expected for 2008-09. The economy grew strongly in 2006-07, driven by robust exports and investment. Employment growth accelerated and has reached historical highs, while unemployment remains significantly lower than in the euro area. Looking ahead, growth is expected to soften to around 2 percent in 2008-09, as activity in trading partners dampens. Risks to this outlook are balanced. 
31. Inflation has increased considerably and continued wage moderation will be essential to maintain Austria's competitiveness and relatively low unemployment. As elsewhere in Europe, inflation in Austria went up due to sharp increases in energy and food prices. So far, there is little indication of a wage-price spiral: wages have been increasing moderately, despite higher labor demand, and unit labor costs have been contained. This is welcome, as significant wage increases would worsen Austria's healthy external position, with negative repercussions for growth, exports, and employment.

\section{Staff strongly supports the government's objective of targeting a balanced} budget over the cycle, but current policies are unlikely to deliver a structurally balanced budget by 2010. The deficit for 2007 was smaller than projected, but this primarily reflected the effect of the cycle. On a structural basis there has been limited consolidation in recent years, and this pattern is likely to be repeated in 2008. Although the government's projections imply strong consolidation in 2009-10, measures to deliver this outcome have not yet been identified, while a substantial tax cut has been announced for 2010. Under the current economic outlook the automatic stabilizers should be allowed to operate.

33. Efforts to reform fiscal federal relations should be intensified. Notwithstanding the political difficulties, reform of fiscal federal relations should be given high priority as it is key to achieving major and lasting expenditure savings and efficiency gains. Reform should focus on strengthening accountability and incentive structures at the sub-national level.

34. The introduction of a medium-term budgetary framework later this year will be a major step forward. For the new framework to be most useful, long term considerations, such as the implications of aging, should be integrated into the framework. Sub-national governments should be fully incorporated as well.

35. The Austrian financial system is generally robust. Soundness indicators for banks and other financial institutions are at satisfactory levels, and 2007 has been a good year for the industry. Improved cost efficiency has helped restore the profitability of domestic operations.

36. The financial system's rapid expansion into CESE and the CIS has brought higher profits and diversification, but also increased risks. Some economies in the region exhibit large macroeconomic imbalances, while certain individual institutions have large exposures to individual markets. The significant volume of foreign currency denominated lending represents a risk factor that deserves special attention by supervisors and banks' risk managers. Stress tests conducted as part of the FSAP Update exercise indicate considerable resilience, while confirming these pressure points.

37. The recent global financial market turmoil has not had a major short-term impact on Austrian banks, but has increased funding costs. Banks' direct exposures to 
affected asset classes and off-balance sheet risks seem to be modest. Funding costs and risk premia are likely to remain elevated, which will make it more expensive to expand credit in CESE and CIS countries.

38. The recent amendment of the bank supervisory framework will require close cooperation between the OeNB and FMA. The amendments have clarified that the FMA, besides its responsibilities in the nonbank area, retains overall responsibility for banking supervision, while banking inspection and analysis has been assigned wholly to the OeNB. For the new financial supervisory structure to be effective, the OeNB and FMA will need to be committed to seamless cooperation; worthwhile initiatives to enshrine this cooperation in operational procedures are already under way.

39. Financial sector oversight has become more demanding and more reliance must be placed on international cooperation and direct supervision by the authorities. Financial institutions and their operations have become more complex, and the supervisory authorities will need to conduct effective and timely on- and off-site supervision. In addition, Austria should continue its efforts to develop cross-border supervisory arrangements. The effectiveness of supervision would also be enhanced by providing better legal protection for supervisory action; the current broad definition of institutional liability ("Amtshaftung") is not in line with international practice, costly to the taxpayer, and creates moral hazard.

40. Recent structural reforms are welcomed, and the authorities are encouraged to focus on further measures that support competition. Recent reforms include the relaxation of regulations on working and shop opening hours. There is scope for increasing competition in the free professions, and full implementation of the EU directive on services would further deregulate the services sector and foster entry and competition. Pension reforms should be implemented firmly to contribute to long-run fiscal sustainability and encourage labor market participation and flexibility. Initiatives to enhance public and private sector R\&D in the context of the Lisbon agenda are welcomed, provided the costeffectiveness of these measures is ensured.

\section{Staff commends Austria for its official development assistance reaching} 0.5 percent of GNP in 2007; it encourages a further increase towards the UN target of 0.7 percent of GNP.

42. It is proposed that the next Article IV consultation be conducted on the standard 12month cycle. 
Table 1. Austria: Basic Data

Total area

Total population (2006)

83,850 square kilometers

GDP per capita (2007)

8.3 million

US\$ 44,966 (€ 32,800)

\begin{tabular}{|c|c|c|c|c|c|c|c|c|}
\hline & 2002 & 2003 & 2004 & 2005 & 2006 & 2007 & 2008 & 2009 \\
\hline & & & & & & & \multicolumn{2}{|c|}{ Proj. } \\
\hline & \multicolumn{8}{|c|}{ (Percentage changes at constant prices) } \\
\hline \multicolumn{9}{|l|}{ Demand and supply } \\
\hline GDP & 0.9 & 1.2 & 2.3 & 2.0 & 3.3 & 3.4 & 2.1 & 1.7 \\
\hline Total domestic demand & -1.2 & 2.5 & 1.6 & 1.3 & 2.4 & 2.8 & 1.8 & 1.5 \\
\hline Consumption & 0.5 & 1.4 & 1.7 & 2.0 & 2.1 & 1.7 & 1.7 & 1.2 \\
\hline Gross investment & -6.8 & 6.6 & 1.2 & -1.3 & 3.7 & 6.5 & 2.2 & 2.5 \\
\hline of which: Gross fixed investment & -6.0 & 5.9 & 0.1 & 0.3 & 3.8 & 4.8 & 2.2 & 2.5 \\
\hline Foreign balance $1 /$ & 1.9 & -1.2 & 0.9 & 0.8 & 1.3 & 1.2 & 0.5 & 0.3 \\
\hline Exports of goods and nonfactor services & 4.0 & 2.3 & 8.2 & 6.2 & 7.5 & 8.1 & 5.4 & 5.0 \\
\hline Imports of goods and nonfactor services & 0.1 & 5.3 & 6.8 & 5.0 & 5.6 & 6.6 & 5.2 & 5.1 \\
\hline Output gap (percent of potential GDP) & -0.5 & -1.4 & -1.3 & -1.5 & -0.5 & 0.6 & 0.4 & -0.1 \\
\hline & \multicolumn{8}{|c|}{ (Percentage changes; period averages) } \\
\hline \multicolumn{9}{|l|}{ Employment and unemployment } \\
\hline Labor force $2 /$ & 1.1 & 1.1 & 0.5 & 1.2 & 1.1 & 1.3 & 1.2 & 0.5 \\
\hline Employment 3/ & 0.2 & 0.9 & 0.4 & 1.0 & 1.6 & 1.9 & 1.2 & 0.5 \\
\hline \multicolumn{9}{|l|}{ Unemployment rate (in percent) } \\
\hline Registered 4/ & 6.9 & 7.0 & 7.1 & 7.3 & 6.8 & 6.2 & 6.1 & 6.2 \\
\hline \multirow[t]{2}{*}{ Standardized 4/ } & 4.2 & 4.3 & 4.8 & 5.2 & 4.7 & 4.4 & 4.3 & 4.4 \\
\hline & \multicolumn{8}{|c|}{ (Percentage changes; period averages) } \\
\hline \multicolumn{9}{|l|}{ Prices and incomes } \\
\hline GDP deflator & 1.4 & 1.2 & 2.1 & 1.8 & 1.8 & 2.3 & 2.6 & 1.9 \\
\hline Consumer price index & 1.7 & 1.3 & 2.0 & 2.1 & 1.7 & 2.2 & 2.9 & 2.0 \\
\hline \multirow[t]{2}{*}{ Unit labor costs (manufacturing) } & 0.8 & -0.2 & -9.4 & 0.5 & 0.4 & 0.5 & 0.7 & 0.5 \\
\hline & \multicolumn{8}{|c|}{ (Percent of GDP) } \\
\hline \multicolumn{9}{|l|}{ General government finances 5/ } \\
\hline Revenue & 49.7 & 49.4 & 48.8 & 48.1 & 47.6 & 47.5 & 47.2 & 47.1 \\
\hline Expenditure & 50.5 & 50.9 & 52.7 & 49.7 & 49.2 & 48.2 & 47.9 & 47.7 \\
\hline Balance & -0.8 & -1.5 & -3.9 & -1.6 & -1.6 & -0.7 & -0.7 & -0.7 \\
\hline Structural Balance & -0.6 & -0.7 & -0.8 & -1.0 & -1.6 & -0.9 & -0.7 & -0.6 \\
\hline \multirow[t]{2}{*}{ Gross debt (end of period) } & 65.9 & 64.7 & 63.8 & 63.5 & 61.8 & 59.1 & 57.8 & 56.7 \\
\hline & \multicolumn{8}{|c|}{ (Billions of euros) } \\
\hline \multicolumn{9}{|l|}{ Balance of payments } \\
\hline Trade balance & 1.4 & -1.5 & -0.8 & -1.4 & 0.3 & 1.3 & 1.4 & 0.3 \\
\hline Current account & 5.9 & 3.8 & 4.8 & 4.9 & 6.3 & 8.8 & 9.6 & 9.0 \\
\hline (In percent of GDP) & 2.7 & 1.7 & 2.1 & 2.0 & 2.4 & 3.2 & 3.4 & 3.0 \\
\hline & \multicolumn{8}{|c|}{ (Percent; period average) } \\
\hline \multicolumn{9}{|l|}{ Interest rates 6/ } \\
\hline Three-month interbank rate & 3.3 & 2.3 & 2.1 & 2.2 & 3.1 & 4.3 & 4.8 & $\ldots$ \\
\hline \multirow[t]{2}{*}{ 10-year government bond } & 4.9 & 4.1 & 4.1 & 3.3 & 3.8 & 4.3 & 4.3 & $\ldots$ \\
\hline & \multicolumn{8}{|c|}{ (Levels; period average) } \\
\hline \multicolumn{9}{|l|}{ Exchange rates } \\
\hline Euro per US \$ 6/ & 1.06 & 0.88 & 0.80 & 0.80 & 0.80 & 0.73 & 0.63 & $\ldots$ \\
\hline Nominal effective exchange rate $(2000=100) 7 /$ & 100.5 & 104.0 & 105.5 & 105.3 & 105.5 & 108.0 & 108.0 & $\ldots$ \\
\hline \multicolumn{9}{|l|}{ Real effective exchange rate $(1990=100) 7 /$} \\
\hline ULC based & 98.1 & 102.8 & 106.0 & 108.4 & 106.1 & 106.7 & 108.4 & $\ldots$ \\
\hline CPI based & 101.0 & 104.2 & 105.7 & 105.7 & 105.4 & 106.7 & 107.5 & $\ldots$ \\
\hline
\end{tabular}

Sources: Austrian authorities; Datastream; and IMF staff estimates and projections.

1/ Contribution to GDP growth.

2/ Dependent labor force.

3/ Payroll employment.

4/ In percent of total labor force. The standardized rate is survey-based, according to EU standards.

5/ On ESA95 basis. The Maastricht Excessive Deficit Procedure (EDP) definition differs from this due to the inclusion of revenues

from swaps. 2004 expenditures were recently revised to include a one-off capital transfer to the Austrian Railways amounting

to $2 \frac{1}{2}$ percent of GDP.

6/ 2008 number is for April.

7/ 2008 number is for February. 
Table 2. Austria: Staff's Medium-Term Macroeconomic Framework, 2003-12

\begin{tabular}{|c|c|c|c|c|c|c|c|c|c|c|}
\hline & \multirow[b]{2}{*}{2003} & \multirow[b]{2}{*}{2004} & \multirow[b]{2}{*}{2005} & \multirow[b]{2}{*}{2006} & \multirow[b]{2}{*}{2007} & \multicolumn{5}{|c|}{ Projections } \\
\hline & & & & & & 2008 & 2009 & 2010 & 2011 & 2012 \\
\hline & \multicolumn{10}{|c|}{ (Percentage contribution at 2000 prices) } \\
\hline \multicolumn{11}{|l|}{ National accounts } \\
\hline GDP & 1.2 & 2.3 & 2.0 & 3.3 & 3.4 & 2.1 & 1.7 & 2.2 & 2.2 & 2.2 \\
\hline Domestic demand & 2.4 & 1.5 & 1.2 & 2.3 & 2.6 & 1.7 & 1.4 & 1.8 & 1.9 & 1.9 \\
\hline Final consumption & 1.0 & 1.3 & 1.5 & 1.6 & 1.2 & 1.2 & 0.9 & 1.1 & 1.4 & 1.4 \\
\hline of which: Private consumption & 0.7 & 1.0 & 1.1 & 1.2 & 0.8 & 0.7 & 0.7 & 1.0 & 1.1 & 1.1 \\
\hline Gross investment & 1.4 & 0.3 & -0.3 & 0.8 & 1.4 & 0.5 & 0.5 & 0.6 & 0.5 & 0.5 \\
\hline Exports of goods and nonfactor services & 1.2 & 4.1 & 3.3 & 4.1 & 4.7 & 3.3 & 3.1 & 3.7 & 3.8 & 4.0 \\
\hline Imports of goods and nonfactor services & -2.4 & -3.2 & -2.5 & -2.9 & -3.4 & -2.8 & -2.8 & -3.2 & -3.5 & -3.6 \\
\hline \multicolumn{11}{|c|}{ (Percentage change) } \\
\hline Prices and unemployment & & & & & & & & & & \\
\hline CPI inflation & 1.3 & 2.0 & 2.1 & 1.7 & 2.2 & 2.9 & 2.0 & 1.8 & 1.8 & 1.8 \\
\hline GDP deflator & 1.2 & 2.1 & 1.8 & 1.8 & 2.3 & 2.6 & 1.9 & 1.8 & 1.8 & 1.8 \\
\hline Unemployment & 4.3 & 4.8 & 5.2 & 4.7 & 4.4 & 4.3 & 4.4 & 4.2 & 4.2 & 4.2 \\
\hline \multicolumn{11}{|c|}{ (Percent of GDP) } \\
\hline External accounts & & & & & & & & & & \\
\hline Current account balance & 1.7 & 2.1 & 2.0 & 2.4 & 3.2 & 3.4 & 3.0 & 2.8 & 2.6 & 2.3 \\
\hline Goods and services balance & 2.8 & 3.0 & 3.2 & 4.1 & 5.0 & 5.1 & 4.7 & 4.5 & 4.2 & 3.8 \\
\hline \multicolumn{11}{|l|}{ General government accounts 1/ } \\
\hline Revenue & 49.4 & 48.8 & 48.1 & 47.6 & 47.5 & 47.2 & 47.1 & 46.0 & 45.9 & 45.8 \\
\hline Expenditure & 50.9 & 52.7 & 49.7 & 49.2 & 48.2 & 47.9 & 47.7 & 47.3 & 46.8 & 46.4 \\
\hline Balance & -1.5 & -3.9 & -1.6 & -1.6 & -0.7 & -0.7 & -0.7 & -1.3 & -0.9 & -0.6 \\
\hline Gross debt & 64.7 & 63.8 & 63.5 & 61.8 & 59.1 & 57.8 & 56.7 & 56.4 & 55.0 & 53.4 \\
\hline Structural balance & -0.7 & -0.8 & -1.0 & -1.6 & -0.9 & -0.7 & -0.6 & -1.3 & -0.9 & -0.6 \\
\hline \multicolumn{11}{|l|}{ Memorandum items: } \\
\hline Gross national saving (percent of GDP) & 23.4 & 23.4 & 22.7 & 23.3 & 24.5 & 24.7 & 24.5 & 24.5 & 24.2 & 24.0 \\
\hline Gross domestic investment (percent of GDP) & 21.8 & 21.4 & 20.7 & 20.9 & 21.3 & 21.3 & 21.5 & 21.6 & 21.7 & 21.7 \\
\hline
\end{tabular}

Sources: Austrian authorities; IMF, International Financial Statistics; and IMF staff estimates and projections.

1/ On ESA95 basis. The Maastricht Excessive Deficit Procedure (EDP) definition differs from this due to the inclusion of revenues from swaps. 2004 expenditures were recently revised to include a one-off capital transfer to the Austrian Railways amounting to $2 \frac{1}{2}$ percent of GDP. 
Table 3. Austria: Balance of Payments, 2003-12

\begin{tabular}{|c|c|c|c|c|c|c|c|c|c|c|}
\hline & \multicolumn{10}{|c|}{ Projections } \\
\hline & 2003 & 2004 & 2005 & 2006 & $2007^{-1}$ & 2008 & 2009 & 2010 & 2011 & 2012 \\
\hline & \multicolumn{10}{|c|}{ (In percent of GDP) } \\
\hline Current account & 1.7 & 2.1 & 2.0 & 2.4 & 3.2 & 3.4 & 3.0 & 2.8 & 2.6 & 2.3 \\
\hline Trade & 2.8 & 3.0 & 3.2 & 4.1 & 5.0 & 5.1 & 4.7 & 4.5 & 4.2 & 3.8 \\
\hline Exports & 47.2 & 50.3 & 53.0 & 55.6 & 58.2 & 59.4 & 60.6 & 62.0 & 63.5 & 64.9 \\
\hline Imports & 44.4 & 47.3 & 49.8 & 51.5 & 53.3 & 54.3 & 55.9 & 57.5 & 59.3 & 61.1 \\
\hline Goods & -0.7 & -0.3 & -0.6 & 0.1 & 0.5 & 0.5 & 0.1 & 0.0 & -0.3 & -0.6 \\
\hline Exports & 34.4 & 37.4 & 39.1 & 41.3 & 43.3 & 44.1 & 45.0 & 46.3 & 47.6 & 49.0 \\
\hline Imports & 35.1 & 37.8 & 39.7 & 41.2 & 42.8 & 43.6 & 44.9 & 46.4 & 48.0 & 49.6 \\
\hline Nonfactor services & 3.5 & 3.4 & 3.8 & 3.9 & 4.5 & 4.7 & 4.6 & 4.6 & 4.5 & 4.4 \\
\hline Exports & 12.7 & 12.9 & 13.9 & 14.3 & 14.9 & 15.3 & 15.6 & 15.7 & 15.8 & 15.9 \\
\hline Imports & 9.3 & 9.5 & 10.1 & 10.3 & 10.4 & 10.7 & 11.0 & 11.1 & 11.3 & 11.5 \\
\hline Balance on factor income & -0.4 & -0.4 & -0.7 & -1.1 & -1.4 & -1.4 & -1.3 & -1.3 & -1.2 & -1.2 \\
\hline Credit & 6.5 & 6.9 & 8.5 & 8.6 & 10.1 & 10.1 & 10.1 & 10.1 & 10.1 & 10.1 \\
\hline Debit & 6.9 & 7.3 & 9.2 & 9.8 & 11.5 & 11.5 & 11.4 & 11.4 & 11.3 & 11.3 \\
\hline Current transfers, net & -0.7 & -0.6 & -0.6 & -0.5 & -0.4 & -0.4 & -0.4 & -0.4 & -0.4 & -0.4 \\
\hline Capital and financial accounts & -0.2 & -0.4 & -0.2 & -2.3 & -2.3 & -3.4 & -3.0 & -2.8 & -2.6 & -2.3 \\
\hline Capital account, net & 0.0 & -0.1 & -0.1 & -0.3 & 0.0 & -0.1 & -0.1 & -0.1 & -0.1 & -0.1 \\
\hline FDI, net & 0.0 & -1.5 & -0.1 & -1.0 & -0.2 & -0.6 & -0.6 & -0.6 & -0.6 & -0.6 \\
\hline Portfolio investment, net & 1.8 & -0.5 & -4.5 & 4.4 & 7.7 & 3.7 & 1.7 & 1.4 & 1.4 & 1.4 \\
\hline Financial derivatives & -0.3 & -0.2 & 0.1 & -0.3 & -0.8 & -0.3 & -0.3 & -0.3 & -0.3 & -0.3 \\
\hline Other & -2.5 & 1.2 & 4.2 & -5.4 & -8.3 & -6.1 & -3.8 & -3.3 & -3.0 & -2.7 \\
\hline Reserve assets & 0.8 & 0.7 & 0.2 & 0.2 & -0.7 & 0.0 & 0.0 & 0.0 & 0.0 & 0.0 \\
\hline Errors and omissions & -1.4 & -1.7 & -1.8 & -0.1 & -0.9 & 0.0 & 0.0 & 0.0 & 0.0 & 0.0 \\
\hline
\end{tabular}

Sources: Austrian National Bank; IMF; and staff projections. 
Table 4. Austria: General Government Accounts, 2002-10

(In percent of GDP, unless otherwise indicated)

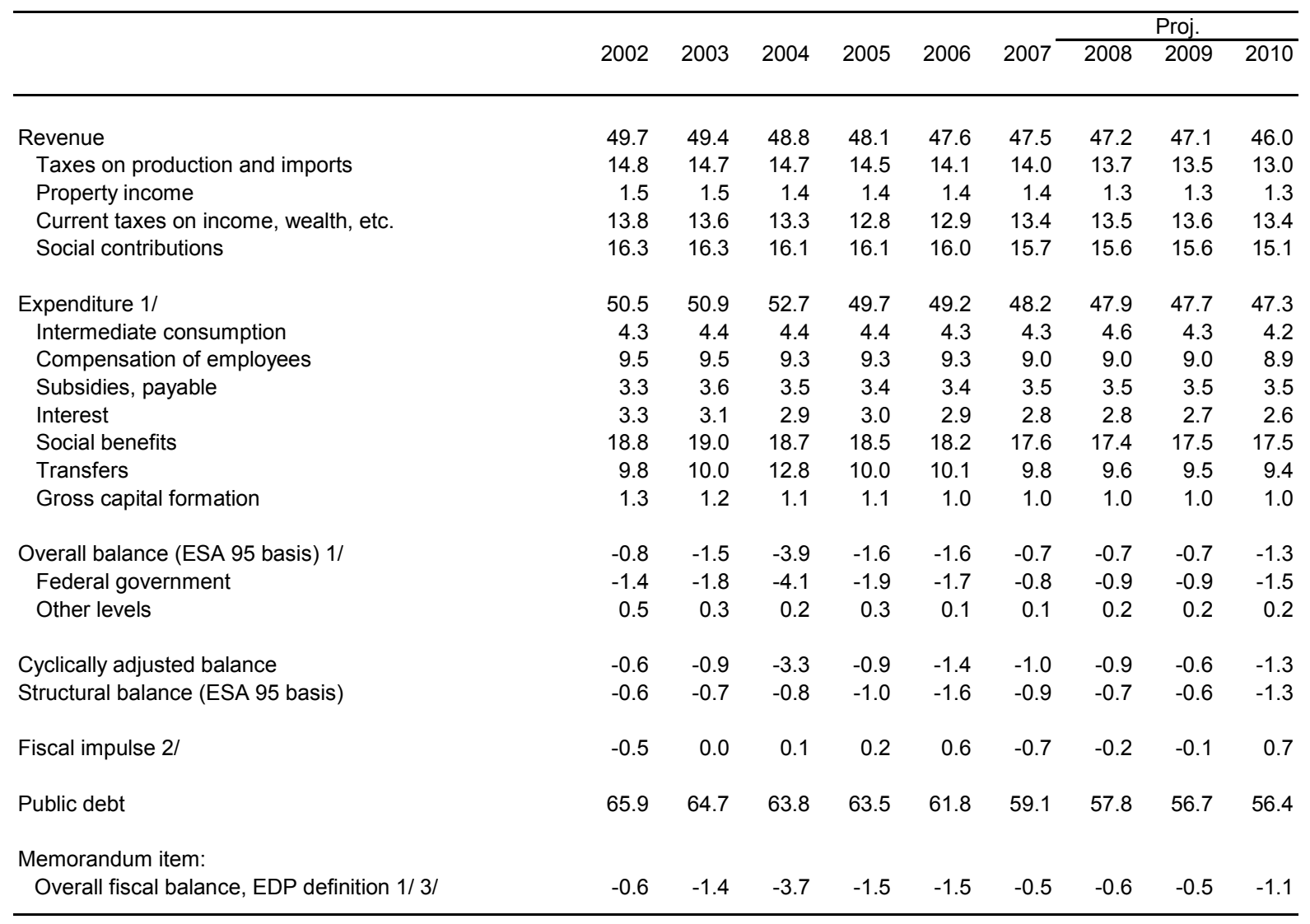

Sources: Federal Ministry of Finance; Austrian Stability Program; and IMF staff estimates and projections.

$1 / 2004$ expenditures were recently revised to include a one-off capital transfer to the Austrian Railways amounting to $2 \frac{1}{2}$ percent of GDP.

2/ Negative of the change in the structural balance.

3/ The Maastricht Excessive Deficit Procedure (EDP) definition is used by the Austrian authorities. The difference from ESA95 is due to the inclusion of revenues from swaps. 
Table 5. Austria: Financial Soundness Indicators for the Banking Sector, 2004-2007

(In percent, end-of-period)

\begin{tabular}{|c|c|c|c|c|c|c|c|}
\hline & \multirow[t]{2}{*}{2004} & \multirow[t]{2}{*}{2005} & \multirow[t]{2}{*}{2006} & \multirow[t]{2}{*}{2007} & \multicolumn{3}{|c|}{2007 Percent Quartiles } \\
\hline & & & & & 25 & 50 & 75 \\
\hline \multicolumn{8}{|l|}{ Capital adequacy } \\
\hline Regulatory capital to risk-weighted assets & 12.4 & 11.8 & 11.8 & 12.7 & 11.9 & 14.9 & 19.3 \\
\hline Regulatory Tier I capital to risk-weighted assets & 8.5 & 8.2 & 8.0 & 8.9 & 9.5 & 12.7 & 16.9 \\
\hline Capital to assets & 4.9 & 4.8 & 5.2 & 6.5 & 5.5 & 7.9 & 10.9 \\
\hline \multicolumn{8}{|l|}{ Asset composition } \\
\hline \multicolumn{8}{|l|}{ Sectoral distribution of bank credit to total gross bank credits } \\
\hline Nonbank financial institutions & 3.0 & 3.6 & 3.7 & 3.3 & 0.0 & 0.0 & 0.5 \\
\hline Nonfinancial corporations & 22.4 & 20.4 & 19.7 & 18.6 & 5.7 & 13.5 & 22.3 \\
\hline Households & 19.8 & 20.1 & 18.9 & 18.0 & 23.7 & 41.0 & 51.8 \\
\hline housing loans & 10.3 & 10.1 & 10.4 & 9.9 & $\ldots$ & $\ldots$ & $\ldots$ \\
\hline personal loans & 9.4 & 10.0 & 8.5 & 8.1 & $\ldots$ & $\ldots$ & $\ldots$ \\
\hline Public sector & 6.4 & 5.4 & 4.9 & 4.0 & 0.1 & 2.1 & 5.3 \\
\hline Nonresident non-banks & 11.5 & 12.9 & 13.7 & 15.9 & 0.2 & 1.1 & 3.8 \\
\hline Domestic and non-domestic banks & 37.1 & 37.6 & 39.1 & 40.2 & $\ldots$ & $\ldots$ & $\ldots$ \\
\hline \multicolumn{8}{|l|}{ Geographical distribution of loans to total loans } \\
\hline Domestic & 73.4 & 70.6 & 68.6 & 66.1 & $\ldots$ & $\ldots$ & $\ldots$ \\
\hline Cross-border & 26.6 & 29.4 & 31.4 & 33.9 & $\ldots$ & $\ldots$ & $\ldots$ \\
\hline EMU & 8.2 & 10.1 & 10.2 & 11.3 & $\ldots$ & $\ldots$ & $\ldots$ \\
\hline CEEC & n.a. & 9.4 & 9.6 & 12.3 & $\ldots$ & $\ldots$ & $\ldots$ \\
\hline Other & n.a. & 9.9 & 11.6 & 10.3 & $\ldots$ & $\ldots$ & $\ldots$ \\
\hline \multicolumn{8}{|l|}{ Asset quality } \\
\hline Nonperforming loans to total gross loans $1 /$ & 2.7 & 2.6 & 2.1 & $\ldots$ & 1.8 & 3.2 & 5.2 \\
\hline doubtful & 1.7 & 1.6 & 1.2 & $\ldots$ & $\ldots$ & $\ldots$ & $\ldots$ \\
\hline irrecoverable & 0.9 & 1.0 & 0.9 & $\ldots$ & $\ldots$ & $\ldots$ & $\ldots$ \\
\hline Loan loss provisions to loans to non-banks (domestic and non-domestic) & 3.3 & 3.1 & 2.9 & 2.4 & $\ldots$ & $\ldots$ & $\ldots$ \\
\hline Loan-loss provisions to nonperforming loans & 70.8 & 71.5 & 75.3 & $\ldots$ & $\ldots$ & $\ldots$ & $\ldots$ \\
\hline Nonperforming loans net of loan-loss provisions to Tier 1 capital $1 /$ & 15.5 & 15.1 & 9.6 & $\ldots$ & -0.1 & 0.0 & 13.5 \\
\hline Total foreign currency-denominated loans to total loans & 24.4 & 25.9 & 24.8 & 23.6 & 2.4 & 7.9 & 15.0 \\
\hline Foreign currency-denominated loans to residents to total claims on residents & 19.0 & 20.1 & 18.7 & 16.2 & $\ldots$ & $\ldots$ & $\ldots$ \\
\hline Foreign currency-denominated loans to households to total claims on households & 29.3 & 31.0 & 30.8 & 27.4 & $\ldots$ & $\ldots$ & $\ldots$ \\
\hline Foreign currency-denominated loans to corporations to total claims on corporations & 14.6 & 13.4 & 10.8 & 8.1 & $\ldots$ & $\ldots$ & $\ldots$ \\
\hline Large exposures to capital (above 10 percent) & 85.8 & 89.7 & 77.5 & 56.4 & 20.8 & 58.3 & 115.4 \\
\hline 10-largest credit to net credits (loans to nonbanks) & 5.0 & 6.8 & 6.8 & 6.0 & $\ldots$ & $\ldots$ & $\ldots$ \\
\hline \multicolumn{8}{|l|}{ Earnings and profitability } \\
\hline Return on assets $2 /$ & 0.6 & 0.6 & 0.7 & 0.7 & 0.3 & 0.6 & 0.8 \\
\hline Return on equity $2 /$ & 14.8 & 14.8 & 16.9 & 16.8 & 4.1 & 6.4 & 9.9 \\
\hline Net interest margin (net interest income / interest bearing assets) & 1.2 & 1.1 & 1.0 & 1.0 & $\ldots$ & $\ldots$ & $\ldots$ \\
\hline Gross income to average assets & 2.3 & 2.3 & 2.2 & 2.1 & $\ldots$ & $\ldots$ & $\ldots$ \\
\hline Net interest income to gross income $2 /$ & 74.3 & 72.2 & 71.1 & 69.1 & 76.1 & 83.2 & 89.8 \\
\hline Trading income to gross income & 4.2 & 4.1 & 4.1 & 1.7 & 0.0 & 0.1 & 0.5 \\
\hline Noninterest expenses to gross income $2 /$ & 72.9 & 71.9 & 68.8 & 66.4 & 65.1 & 72.3 & 80.5 \\
\hline Personnel expenses to noninterest expenses & 50.1 & 50.1 & 50.5 & 50.4 & 53.5 & 58.4 & 62.1 \\
\hline Spread between domestic lending and deposit rates & 1.3 & 1.2 & 0.9 & 0.8 & $\ldots$ & $\ldots$ & $\ldots$ \\
\hline \multicolumn{8}{|l|}{ Liquidity } \\
\hline Liquid assets to total assets & 28.9 & 27.4 & 27.6 & 26.8 & 20.4 & 25.3 & 34.1 \\
\hline Liquid assets to short-term liabilities & 73.8 & 68.0 & 68.6 & 67.0 & 64.4 & 90.6 & 114.0 \\
\hline Foreign currency-denominated liabilities to total liabilities & 20.3 & 20.5 & 20.0 & 17.2 & 2.7 & 7.0 & 12.5 \\
\hline Deposits to assets & 66.1 & 65.3 & 63.8 & 62.6 & $\ldots$ & $\ldots$ & $\ldots$ \\
\hline Loans to deposits & 113.9 & 112.9 & 115.8 & 116.3 & $\ldots$ & $\ldots$ & $\ldots$ \\
\hline Sensitivity to market risk & & & & & & & \\
\hline Off-balance sheet operations to assets & 224.6 & 207.5 & 208.1 & 200.2 & $\ldots$ & $\ldots$ & $\ldots$ \\
\hline interest rate contracts & 190.1 & 171.9 & 170.7 & 187.8 & $\ldots$ & $\ldots$ & $\ldots$ \\
\hline forex contracts & 33.1 & 33.1 & 35.1 & 38.6 & $\ldots$ & $\ldots$ & $\ldots$ \\
\hline other derivatives & 1.3 & 2.4 & 2.5 & 2.2 & $\ldots$ & $\ldots$ & $\ldots$ \\
\hline Duration of assets to total assets & & & & & & & \\
\hline Less than 3 months & 51.2 & 61.1 & 59.3 & 62.4 & $\ldots$ & $\ldots$ & $\ldots$ \\
\hline Between 3 months and 1 year & 14.7 & 13.7 & 12.2 & 13.4 & $\ldots$ & $\ldots$ & $\ldots$ \\
\hline Between 1 and 5 years & 13.9 & 12.4 & 11.5 & 10.7 & $\ldots$ & $\ldots$ & $\ldots$ \\
\hline More than 5 years & 8.2 & 8.3 & 8.1 & 7.6 & $\ldots$ & $\ldots$ & $\ldots$ \\
\hline Duration of liabilities to total liabilities & & & & & & & \\
\hline Less than 3 months & 49.1 & 58.6 & 54.4 & 56.9 & $\ldots$ & $\ldots$ & $\ldots$ \\
\hline Between 3 months and 1 year & 12.7 & 13.4 & 13.5 & 14.6 & $\ldots$ & $\ldots$ & $\ldots$ \\
\hline Between 1 and 5 years & 16.6 & 14.8 & 14.0 & 12.4 & $\ldots$ & $\cdots$ & $\cdots$ \\
\hline More than 5 years & 9.2 & 9.1 & 8.9 & 10.0 & $\ldots$ & $\ldots$ & $\ldots$ \\
\hline Net open position in foreign exchange to capital & 2.1 & 3.3 & 3.8 & 1.5 & 0.1 & 0.9 & 3.3 \\
\hline
\end{tabular}

1/ Data as of end-2006.

2/ 2007 numbers refer to the third quarter. 


\section{INTERNATIONAL MONETARY FUND}

AUSTRIA

\section{Staff Report for the 2008 Article IV Consultation-Informational Annex}

Prepared by the Staff Representatives for the 2008 Consultation with Austria (In Consultation with Other Departments)

May 22, 2008

\section{Contents}

I. Fund Relations .......

II. Statistical Issues . 


\section{Annex I. Austria: Fund Relations}

(As of April 30, 2008)

Mission: Consultation discussions were held in Vienna during March 7-17, 2008. The authorities released the mission's concluding statement, which is available at: http://www.imf.org/external/np/ms/2008/031708.htm.

Staff team: Messrs. Hilbers (head), Kanda, Lundback, Rosenberg (all EUR), and Hardy (MCM). Mr. Prader, Alternate Executive Director for Austria, attended the meetings.

Country interlocutors: The Vice-Chancellor and Minister of Finance; the Minister of Economics and Labor; the Governor of the Austrian National Bank (OeNB); the Chief Executive Officers of the Financial Market Authority (FMA); and senior officials at the federal and lower level governments, the OeNB, and the FMA. The mission also met with the parliamentary budget committee, representatives of economic research institutes, employers' organizations, the federation of trade unions, and commercial banks. There was a press conference at the end of the mission.

Fund relations: Austria is on a 12-month consultation cycle. The last consultation was completed on April 23, 2007. The reports is available at: http://www.imf.org/external/pubs/cat/longres.cfm?sk=20670.0

FSAP Update: An FSAP Update, with a mission during November 27-December 11, 2007, was conducted in parallel with the 2008 Article IV consultation.

I. Membership Status:

(a) Joined: August 27, 1948

(b) Status: Article VIII, as from August 1, 1962

II. General Resources Account:

Quota

Fund holdings of currency

Reserve position in Fund

III. SDR Department:

Net cumulative allocation Holdings

IV. Outstanding Purchases and Loans:

V. Latest Financial Arrangements:

None

None
SDR Million

$1,872.30$

Percent Quota

100.00

$1,738.09$

92.83

134.21

7.17

SDR Million

Percent Allocation

179.05

100.00

147.58

82.43 
VI. Projected Payments to Fund:

(SDR Million; based on existing use of resources and present holdings of SDRs):

Principal

Charges/Interest

Total
Forthcoming

\begin{tabular}{rrrrr}
2008 & 2009 & 2010 & 2011 & 2012 \\
\hline-- & -- & -- & -- & -- \\
0.65 & 0.87 & 0.87 & 0.87 & 0.87 \\
0.65 & 0.87 & 0.87 & 0.87 & 0.87 \\
\hline
\end{tabular}

\section{Exchange System:}

As of January 1, 1999, the currency of Austria is the euro. Austria's exchange system is free of restrictions on the making of payments and transfers for current international transactions with the exception of restrictions notified to the Fund in accordance with decision No. 144(52/51) resulting from UN Security Council Resolutions and EU Council regulations. The most recent notification was made on March 19, 2008. Furthermore, national restrictions apply with respect to certain terror organizations and their activists within the EU, implementing decisions in the Common Foreign and Security Policy (CFSP) framework of the EU. 


\section{Annex II. Austria: Statistical Issues}

Macroeconomic statistics are adequate for surveillance. Austria subscribed to the Fund's Special Data Dissemination Standard (SDDS) in 1996, and its metadata are available on the Fund's electronic Dissemination Standards Bulletin Board. Austria is availing itself of the SDDS flexibility option on the timeliness of the industrial production index and the merchandise trade data.

The transition to the new European System of Accounts 1995 (ESA 1995) has complicated the analysis of national accounts and fiscal data. The new national accounts do not provide information on household disposable income, except for an economy-wide aggregate, thus precluding the calculation of a household saving ratio. In addition, the reclassification of public hospitals in 1997 introduced a break in the national account series on public and private consumption. Annual fiscal data for 1995 onward are derived from ESA 1995 data reported to Eurostat, using bridge tables created in a collaborative effort by the Fund and Eurostat. Data on outlays by function have been revised and are available from 1995 onward on a comparable basis according to major functional categories. Reported data on the net acquisition of financial assets and net incurrence of liabilities exclude a breakdown between domestic and foreign financing. Quarterly fiscal data reported through Eurostat are disseminated in the IFS.

The ECB reporting framework is used for monetary statistics and data are reported to the IMF through a "gateway" arrangement with the ECB. The arrangement provides an efficient transmission of monetary statistics to the IMF and for publication in the IFS and IFS Supplement. 


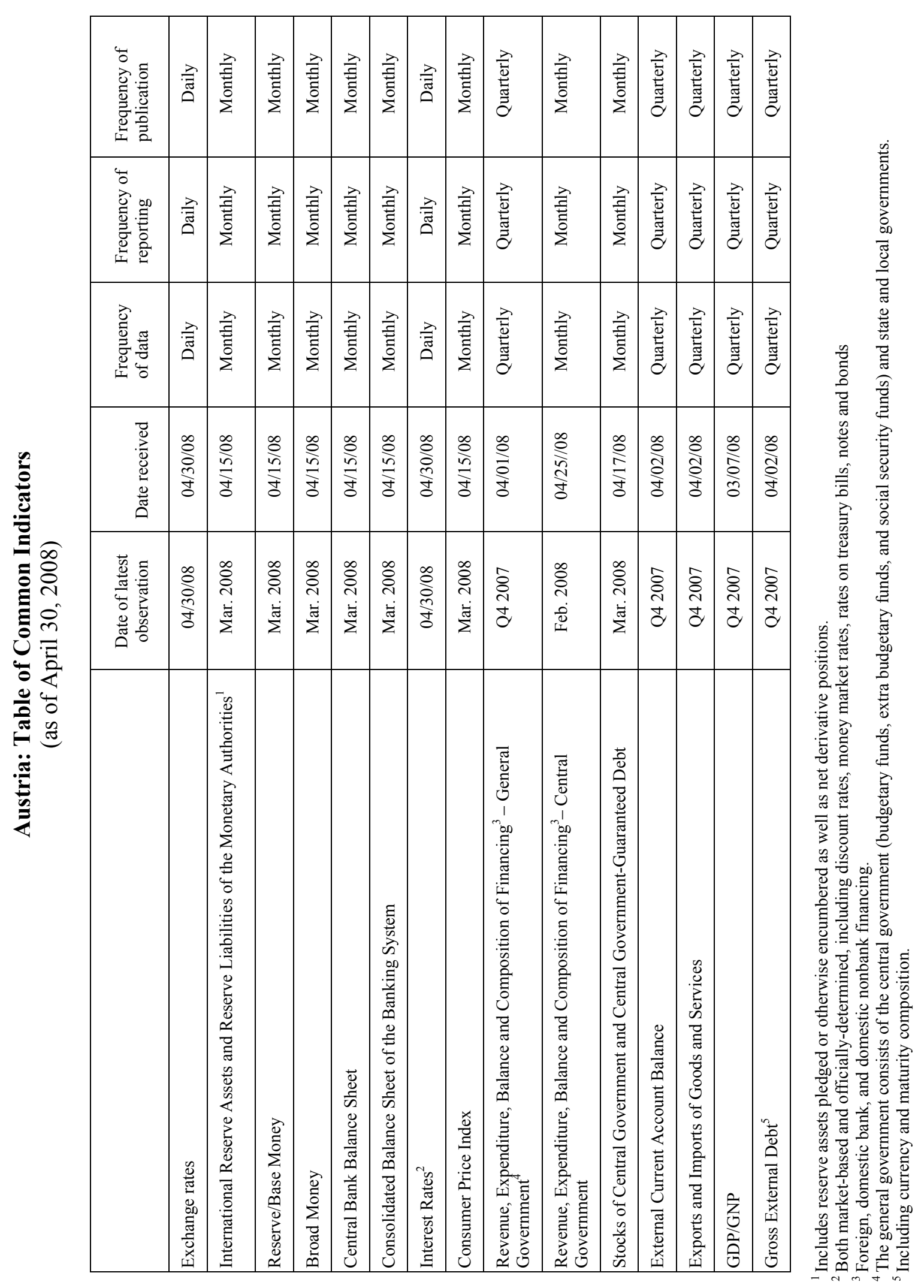




\section{INTERNATIONAL MONETARY FUND}

Public Information Notice (PIN) No. 08/72

FOR IMMEDIATE RELEASE

June 19, 2008
International Monetary Fund $70019^{\text {th }}$ Street, NW

Washington, D. C. 20431 USA

\section{IMF Executive Board Concludes 2008 Article IV Consultation with Austria}

On June 13, 2008, the Executive Board of the International Monetary Fund (IMF) concluded the Article IV consultation with Austria. ${ }^{1}$

\section{Background}

Solid economic policies, wage moderation, and an early focus on Central, Eastern, and South Eastern Europe (CESE) explain Austria's strong economic performance in the past period. Economic policies have contributed to this performance by focusing on macroeconomic stability and structural reforms. Wage moderation, resulting from a strong social partnership, has preserved competitiveness and supported export led growth, which has significantly exceeded the euro area average in the past period.

In line with developments in major trading partners, a slowdown is expected for 200809. The economy grew strongly in 2006-07: real GDP increased by more than 3 percent in both years, driven by robust exports and investment. Looking ahead, the growth momentum is expected to soften in the course of the year as activity in trading partners dampens and growth is projected to slow to around 2 percent in 2008-09.

\footnotetext{
${ }^{1}$ Under Article IV of the IMF's Articles of Agreement, the IMF holds bilateral discussions with members, usually every year. A staff team visits the country, collects economic and financial information, and discusses with officials the country's economic developments and policies. On return to headquarters, the staff prepares a report, which forms the basis for discussion by the Executive Board. At the conclusion of the discussion, the Managing Director, as Chairman of the Board, summarizes the views of Executive Directors, and this summary is transmitted to the country's authorities. This PIN summarizes the views of the Executive Board as expressed during the Executive Board discussion based on the staff report.
} 
Austria's external position remains strong, despite a recent decline in competitiveness. The current account turned positive in 2002 and has remained strong on account of strong exports of goods and non-factor services. This reflects a period of wage moderation combined with robust productivity growth, resulting in strengthened competitiveness. In the last year, the Unit Labor Cost (ULC) based Real Effective Exchange Rate (REER) has started to edge up again, but it still compares favorably with the euro area.

Inflation has increased, but there is so far little indication of a wage-price spiral. As elsewhere in Europe, headline inflation in Austria went up due to sharp increases in energy and food prices, while core inflation has been contained. Recent wage agreements between social partners for 2008 are higher than in recent years, but are still moderate.

The general government fiscal deficit narrowed significantly in 2007 and the public debt ratio came down below the Maastricht reference value of 60 percent of GDP. However, the structural deficit is still estimated at around 1 percent and over the last few years there has been limited structural improvement.

The Austrian financial system is generally robust. Soundness indicators for banks and other financial institutions are at satisfactory levels, and 2007 seems to have been a good year for the industry. The recent global financial market turmoil has not had a major short-term impact on Austrian banks, but has increased funding costs. Banks' direct exposures to affected asset classes and off-balance sheet risks seem to be modest. Were funding costs and risk premia to remain elevated, expansion of credit in CESE would be dampened.

\section{Executive Board Assessment}

Executive Directors commended Austria's continued strong economic performance, which has been driven by robust exports and investment. Economic growth is significantly above the euro area average, employment growth has accelerated and unemployment remains lower than in the euro area, and the public debt to GDP ratio has declined. The strong performance reflects sound economic policies, wage moderation, and a significant engagement in Central, Eastern, and Southeastern European economies. Directors considered that the main challenges facing the Austrian authorities are to maintain external competitiveness, ensure fiscal sustainability, and continue strengthening financial regulation and supervision.

Directors noted that inflation has increased sharply because of higher energy and food prices, although so far there is little indication of second-round effects. Wages have been increasing moderately, despite higher labor demand, and unit labor costs have been contained. Nevertheless, Directors stressed that, with inflation risks tilted to the 
upside, continued wage moderation and structural reforms will be essential to maintaining Austria's competitiveness and relatively low unemployment.

Directors noted that there has been limited consolidation of the structural budget balance in recent years despite strong economic growth. Directors supported the government's objective of achieving a structurally balanced budget by 2010 , but cautioned that current policies, including a substantial tax cut announced for 2010, are unlikely to deliver this outcome. Given the planned reduction in the tax burden, Directors called on the authorities to identify concrete expenditure-based measures that will be implemented to achieve the fiscal objective. They pointed to healthcare, pensions, and fiscal federalism as key areas of spending restraint and potential efficiency gains.

Directors encouraged the authorities to intensify efforts to reform fiscal federal relations. While recognizing the political difficulties, Directors emphasized that such reform should be given high priority as it is key to achieving major and lasting expenditure savings and efficiency gains. Directors welcomed the planned introduction of a medium-term budgetary framework with fixed expenditure ceilings later this year.

Directors welcomed the Financial Sector Assessment Program update's finding that the Austrian financial system is profitable, well-capitalized and liquid, and resilient to shocks. They noted that the recent global financial market turmoil has not had a major impact on Austrian banks. While the financial system's rapid expansion into Central, Eastern, and Southeastern Europe has brought higher profits and diversification, Directors noted it also has increased risks. In particular, Directors pointed out that rapid credit growth and the significant volume of foreign currency denominated lending represent risk factors that deserve special attention by supervisors and banks' risk managers.

Directors noted that financial sector oversight has become more demanding, a key challenge being to ensure adequate risk management in the context of growing crossborder financial integration and increasing complexity of financial operations. They called for strengthening of cross-border supervisory arrangements and on- and off-site supervision. They noted the recent amendment of Austria's bank supervisory framework, which resulted in an enhanced role for the Austrian National Bank, and emphasized that the new framework will require close cooperation between the National Bank and the Financial Market Authority. Directors considered that the effectiveness of supervision would be enhanced through better legal protection for supervisory action. Directors welcomed recent structural reforms in product and labor markets, including the relaxation of regulations on working and shop opening hours. They encouraged the authorities to focus on further measures that support competition, including compliance with the EU directive on services liberalization. They recommended that pension reforms be implemented firmly to enhance long-run fiscal sustainability and encourage labor market participation and flexibility. 
Directors commended Austria for increasing its official development assistance to 0.5 percent of GNP in 2007, and encouraged the authorities to continue to move toward the UN target of 0.7 percent of GNP.

Public Information Notices (PINs) form part of the IMF's efforts to promote transparency of the IMF's views and analysis of economic developments and policies. With the consent of the country (or countries) concerned, PINs are issued after Executive Board discussions of Article IV consultations with member countries, of its surveillance of developments at the regional level, of post-program monitoring, and of ex post assessments of member countries with longer-term program engagements. PINs are also issued after Executive Board discussions of general policy matters, unless otherwise decided by the Executive Board in a particular case. The staff report (use the free Adobe Acrobat Reader to view this pdf file) for the 2008 Article IV Consultation with Austria is also available. 
Austria: Selected Economic Indicators

\begin{tabular}{|c|c|c|c|c|c|}
\hline & 2004 & 2005 & 2006 & 2007 & $\begin{array}{c}2008 \\
\text { proj. }\end{array}$ \\
\hline \multicolumn{6}{|l|}{ Real economy } \\
\hline Real GDP (change in percent) & 2.3 & 2.0 & 3.3 & 3.4 & 2.1 \\
\hline Domestic demand (change in percent) & 1.6 & 1.3 & 2.4 & 2.8 & 1.8 \\
\hline CPI (period average, percent change) & 2.0 & 2.1 & 1.7 & 2.2 & 2.9 \\
\hline Unemployment rate (in percent) & 4.8 & 5.2 & 4.7 & 4.4 & 4.3 \\
\hline Gross national saving (percent of GDP) & 23.4 & 22.7 & 23.3 & 24.5 & 24.7 \\
\hline Gross domestic investment (percent of GDP) & 21.4 & 20.7 & 20.9 & 21.3 & 21.3 \\
\hline \multicolumn{6}{|l|}{ Public finance (in percent of GDP) } \\
\hline Central government balance & -4.1 & -1.9 & -1.7 & -0.8 & -0.9 \\
\hline General government balance & -3.9 & -1.6 & -1.6 & -0.7 & -0.7 \\
\hline General government balance (EDP) $1 /$ & -3.7 & -1.5 & -1.5 & -0.5 & -0.6 \\
\hline General government debt & 63.8 & 63.5 & 61.8 & 59.1 & 57.8 \\
\hline \multicolumn{6}{|l|}{ Interest rates (in percent) 2/ } \\
\hline Three-month interbank rate & 2.1 & 2.2 & 3.1 & 4.3 & 4.8 \\
\hline 10-year government bond & 4.1 & 3.3 & 3.8 & 4.3 & 4.3 \\
\hline \multicolumn{6}{|l|}{ Balance of payments (percent of GDP) } \\
\hline Trade balance including services & 3.0 & 3.2 & 4.1 & 5.0 & 5.1 \\
\hline Current account balance & 2.1 & 2.0 & 2.4 & 3.2 & 3.4 \\
\hline \multicolumn{6}{|l|}{ Fund position (as of April 30, 2008) } \\
\hline Holdings of currency (percent of quota) & & & & & 92.8 \\
\hline Holdings of SDRs (percent of allocation) & & & & & 82.4 \\
\hline Quota (millions of SDRs) & & & & & 1872.3 \\
\hline \multicolumn{6}{|l|}{ Exchange rates } \\
\hline Exchange rate regime & \multicolumn{4}{|c|}{ EMU Member } & \\
\hline Euro per U.S. dollar 2/ & 0.80 & 0.80 & 0.80 & 0.73 & 0.63 \\
\hline Nominal effective rate $(2000=100)$ & 105.5 & 105.3 & 105.5 & 108.0 & $\ldots$ \\
\hline Real effective rate $(1990=100) 3 /$ & 106.0 & 108.4 & 106.1 & 106.7 & $\ldots$ \\
\hline
\end{tabular}

Sources: Austrian National Bank; Statistics Austria; Ministry of Finance; IMF staff projections.

1/ Maastricht Excessive Deficit Procedure (EDP); includes revenues from swaps.

2/ 2008 numbers are for April.

$3 /$ Based on relative normalized unit labor cost in manufacturing. 


\section{Statement by Johann Prader, Alternate Executive Director for Austria June 13, 2008}

The Austrian authorities welcome the consultations with the Fund and commend the staff for the high quality of the Staff Report. They broadly agree with the staff's assessment of Austria's economic situation and their general recommendations on economic and financial policies. The authorities also welcome the Selected Issues Paper, which sheds light on the fiscal federalism in Austria.

The Staff Report once again highlights Austria's good economic performance relative to its European peers and considers this to be the result of solid economic policies, structural reforms, wage moderation, and an early focus on Central, Eastern and Southeastern Europe (CESE). The authorities welcome the Fund's support for further streamlining the functions of the various levels of government, which will be necessary to control expenditures further.

\section{Short-term outlook}

In 2006 and 2007, the Austrian economy grew by almost $3 \frac{1}{2}$ percent per year. Despite the global financial turmoil, economic growth and employment continued to be buoyant in the first 5 months of 2008 and the economy expanded by $3 \frac{1}{2}$ percent in the first quarter. However, the ongoing financial downturn will also affect Austria and GDP growth is expected to decelerate to an annual growth about $2 \frac{1 / 4}{4}$ percent in the second half of 2008 . The authorities are concerned about the rising consumer price inflation, which was at $31 / 2$ percent in the spring of 2008 . Two thirds of the increase is due to high world prices of food and energy.

\section{Fiscal policy}

At 1.5 percent of GDP, the general government deficit for 2006 was higher than assumed at the time of establishing the fiscal consolidation path for the current legislative period. This deterioration originated primarily from the one-off measures taken by local and state governments. The original target for 2007 was a deficit of 1.1 percent of GDP. The preliminary outcome showed an improvement of 1 percent of GDP as compared with 2006 and thus a deficit of only 0.5 percent of GDP. While planned public expenditures were under firm control, the significantly higher economic growth and a strong increase in employment were used for deficit reduction. Also, the public debt ratio fell below 60 percent for the first time since 1992.

For 2008, the fiscal target is a deficit of 0.6 percent of GDP, which is likely to be met despite some first steps taken to alleviate the tax burden for incomes of up to $€ 1,350$ per month and the advancement of the next pension adjustment to November 2008. The latter measure reflects the currently high inflation, which has affected the purchasing power of pensions, while the first will be counted towards the volume of the envisaged tax reform in 2010 , tentatively set at 1 percent of GDP and still in line with the goal of a balanced budget. The tax reform will be finalized at the time of adopting the 2010 budget. 
In the coming three years, the Austrian economy is expected to grow close to its potential. According to the government agreement, public households should be moving to a structural balance in 2010. Fiscal consolidation will inter alia benefit from the phasing out of the purchase of fighter planes. The government has agreed upon a package of health sector reforms, which will gradually trim expenditures and exploit efficiency gains until 2012. Also, the government intends to introduce an automatic procedure for the adjustment of the parameters driving public pension expenditures, if life expectancy at age 65 increases by more than 6 months in the future, contributing to the financial sustainability of the public pension system.

In the coming years, the authorities will continue with the fiscal "Three-Pillar-Strategy" of Austria:

- Balanced budget by 2010 and stable, sustainable public finances.

- Expenditures focusing on "investments for the future" to further improve growth and employment at a sustainable level.

- Continuing structural and budgetary reforms, to foster the growth potential and simultaneously reducing strains on public expenditures. This should enable the implementation of a tax reform in 2010.

In order to strengthen the structural fiscal balance and avoid slippages from the budget path, a multi-year budget plan, set for four years in advance and updated on a rolling basis with fixed expenditure ceilings, will be implemented from 2009 onwards. The expenditure ceilings will have to be agreed by parliament and only the parliament will be able to change them. In this way, policy will be able to react flexibly to changing priorities, while simultaneously - due to the parliamentary procedures - a sufficient degree of expenditure discipline will be achieved. Flexible budget components will allow the automatic stabilisers to work and thereby react to cyclical conditions. Nevertheless, the final decision on the federal budget will continue to be in the realm of the national parliament.

\section{Perspectives on the reform of fiscal federal relations in Austria}

The agreement of the federal government includes commitments concerning state and local levels. To coordinate the responsibilities and financing schemes between the different levels of government, the fiscal revenue sharing agreement was concluded in October 2007. The new scheme is structured into two periods of three years each. It will be implemented starting January 1, 2008 and will end on December 31, 2013. At the level of states, the sustainability of the health sector was a key issue. From the perspective of the federal government, structural reforms in fiscal revenue sharing and the need to follow up with pension reforms at the state and local levels were stressed.

\section{Challenges to the financial sector in Austria}

The Austrian authorities consider the FSAP-update to be very useful as it presents a balanced view of the state of the Austrian financial sector. As rightly noted in the assessment, many of the main recommendations correspond to the priorities that have been identified by the authorities as well and are already being implemented. 
The FSAP-update points to the robustness of the financial system, which has inter alia been proven by the comprehensive stress tests conducted during the Fund missions. The further integration of the CESE activities of Austrian banks in the stress testing framework, as recommended by the mission team, is an issue that is already on the agenda of the supervisory authorities. In this context, the authorities appreciate that the FSSA report explicitly notes that CESE countries are diverse, a fact that is often not appropriately recognised in discussions.

Moreover, there is also a need to continue raising awareness of borrowers regarding the risks inherent to foreign currency lending and to ensure that banks remain vigilant to the risks stemming from these activities. In this respect, the Financial Market Authority (FMA) and the OeNB have launched a number of activities in the last few years, some of which have been adopted by other countries that face the foreign currency loan phenomenon.

The IMF staff also rightly points out that to date the current global financial market turmoil has not had a major direct effect on Austrian banks. The most recent available data endorse this assessment. In 2007, the value adjustments in the structured product portfolios of the 30 largest Austrian banks approximately amounted to $€ 1.1$ billion, with only a very limited part related to US-subprime securities. For the first quarter of 2008, these banks expect additional value adjustments in structured credit products in the range of $€ 550$ million to $€ 750$ million. Given this background and taking into account the robust capital base and refinancing structure of Austrian banks, a credit crunch or any adverse developments are not expected as a consequence of the recent international turmoil.

Also in the regulatory and supervisory areas, the issues at stake are evident: For the time being, one of the key priorities is the implementation of the recent reform of financial market supervision in Austria, maintaining the FMA as integrated supervisory authority, but assigning the responsibility for comprehensive risk assessment by means of on-site inspections and bank analysis to the OeNB. The two institutions are firmly committed to cooperating closely and have publicly acknowledged their common commitment. It should be emphasized that the practical implementation process of the new approach to inspections and analysis as well as the setting-up of supporting infrastructures - e.g. in terms of the a joint data base - is on track. This goes hand in hand with the enhancing of available staff resources in order to further intensify the depth and frequency of on-site inspections and to develop further the risk-based off-site analysis framework, followed by consistent supervisory measures, if necessary.

In this context, the authorities appreciate the clear opinion provided by the assessment team with regard to the need to limit the extensive public liability provisions being applied to financial sector supervision, not least with a view to the political debate such an issue necessarily implies. 
At the same time, the authorities are giving further emphasis to cross-border banking cooperation, building on the extensive efforts made in this respect over the last few years. Preparations for a regional crisis management exercise are also in the pipeline. 